\title{
Weathering, erosion, and susceptibility to weathering
}

\author{
H. Robert G.K. Hack
}

Engineering Geology, ESA, Faculty of Geo-Information Science and Earth Observation (ITC), University of Twente

Enschede, The Netherlands

e-mail: h.r.g.k.hack@utwente.nl

phone: +31624505442

\begin{abstract}
Soft grounds are often the result of weathering. Weathering is the chemical and physical change in time of ground under influence of atmosphere, hydrosphere, cryosphere, biosphere, and nuclear radiation (temperature, rain, circulating groundwater, vegetation, etc.). Erosion is the removal of material on or below the Earth surface due to flowing (ground-) water, ice, and wind. Quantities of weathered material do not need to be large to change the geotechnical properties of a groundmass, for example, weathering of discontinuity walls that reduce the shear strength. Weathering is the reason for many constructions and other engineering applications in which ground is used, to become a disaster. The processes involved in weathering are described briefly as well as the role of erosion in weathering and weathering depth. The dependence of weathering on lithology, implications for engineering applications, the methodology for describing and classification of weathering, and options for determining the susceptibility to weathering for forecasting future weathering are introduced. Hard layer or crust forming as result of weathering and tests for determining the state of weathering and susceptibility to weathering conclude the chapter.
\end{abstract}

Keywords: Ground, Weathering; Susceptibility to weathering; Geomechanical properties; Degradation; Erosion, Hard layer

\section{Introduction}

Weathering is the change of ground materials under influence of the Earth atmosphere, hydrosphere, cryosphere, biosphere, and by nuclear radiation, mostly causing hard ground to become soft ground. Landslides and instable cut slopes are the most obvious results of weathering but also soil and rock in tunnels may weather and jeopardize tunnel stability. Completely buried ground below foundations of surface structures may weather due to percolating groundwater and air causing a gradual degradation of the geotechnical quality of the ground under a foundation. Under some conditions weathering may have a reverse effect and cause an increase in ground strength when forming 'hard' layers.

Weathering in most grounds is normally a fairly slow process taking long (geological) times to weather a large volume of ground, but it should be realized that small changes of very small quantities of material of a ground by weathering happening in a relatively short time span already may jeopardize an engineering construction. For example, the rock on both sides of a joint plane after excavation being exposed to a new environment may weather by a depth of tens of a millimeter in a couple of days, months, or years after excavation. Then the shear strength of the joint plane may be significantly reduced due to weathering of the asperities on the joint plane and forming a thin layer of low shear strength infill material, e.g. clay, in the joint. Such reduction in shear strength is often enough to allow sliding of a rock block where that would not have been the case along the unweathered joint plane.

Weathering also allows 'loss of structure' of ground. The geotechnical quality of ground is to a certain extent due to a tight structure of particles and blocks of ground material. The tightness of the structure is reduced if weathering causes removal of part of the material or reduces the strength of particles or blocks. The reduction in 
tightness, among others, allows displacements in the ground, reduction of stresses in the ground, reduction of shear strength between particles and blocks, and, hence, the overall geotechnical quality of ground.

Thus, weathering has a major influence on the engineering properties of the ground (Anon. 1995; Hack 1996; Hencher 2015; Tating et al. 2013; Miščević and Vlastelica 2014; ISO 14689-1:2017 ; Fookes 1997; Price et al. 2009). Therefore, weathering and the change of geotechnical properties with time during the lifetime of an engineering construction have to be incorporated in the design of any construction on or below the Earth surface.

Weathering is often assumed to be restricted to the Earth surface, but active weathering may take place deep under the surface, for example, around faults with percolating groundwater down to thousands of meters deep, and at surface weathered material may have moved down into the Earth crust by tectonic and sedimentary processes. Moreover, weathered material may be a relic of weathering under a past climate or environment that has changed since long (Harris et al. 1996; Olesen et al. 2007). Hence, any weathered material can be encountered anywhere at the surface or in the subsurface of the Earth.

\subsection{Definitions}

Weathering in this chapter denotes the chemical, physical and nuclear change of ground due to contact between the ground and the Earth atmosphere, hydrosphere, cryosphere, and biosphere, and due to nuclear radiation, but without any substantial transport of the weathering products. The influence of lightning striking the ground and the influence of bush or underground fires on ground are included in weathering too. Man-action is also of importance as it is often the reason for new or intensified weathering of ground. Some literature identifies a fourth process; biological weathering, but in this chapter biological influence is included in physical and chemical weathering as the processes and mechanisms involved in biological weathering are the same as in physical and chemical weathering. Erosion denotes the transport of weathered material by surface or subsurface processes to another location, i.e. transport by (ground-) water, ice, air, or other agents. In this chapter fragmentation without transport is part of the weathering process. Radiation and emission of particles from the Earth itself, space, or from man-made nuclear materials are collectively denoted 'nuclear radiation'.

The locations on surface and in the subsurface where weathering takes place are also the locations where often stress relief, intact ground creep, and groundmass creep occur. These effects are virtually always impossible to differentiate from effects caused by weathering. Moreover, the effects and weathering interact, for example, stress relief causes displacement of discontinuities that increases permeability, which allows more groundwater to percolate through the ground that intensifies weathering. Vice versa, removal of material due to weathering and erosion allows ground to de-stress, increases permeability, etcetera. Therefore, in this chapter effects of stress relief, intact ground creep, and groundmass creep are included in the definition of weathering as proposed by Price (1995).

Ground materials are diverse and may be gases, fluids, solids (i.e. minerals, grains, and aggregates of grains or minerals), and any mixture of these and include man-made ground, such as fills and waste dump materials. Ground is commonly differentiated into soil and rock; soil being an aggregate of loose or weakly-bonded particles, and rock consisting of particles cemented or locked together, giving rock a tensile strength. Soil and rock are, by some, differentiated based on a compressive strength difference mostly with soil being weaker than $1 \mathrm{MPa}$ and rock being stronger.

A differentiation is made between 'intact' and 'discontinuous' ground, i.e. ground without respectively with distinct planes of mechanical weakness ('mechanical discontinuities'). Faults, joints, bedding planes, fractures, schistosity, foliation, etc. can be mechanical discontinuities. 'Incipient discontinuities' or 'integral discontinuities' are discontinuities that are not yet developed into mechanical discontinuities, i.e. the geotechnical properties of the discontinuity are not yet different from those of the surrounding intact ground. Weathering and changes in stress can be causes for incipient discontinuities to become mechanical, for example, weathering causes incipient bedding planes to become mechanical discontinuities. A groundmass consists of (blocks of) intact ground with discontinuities, if present. In this chapter the terms 'intact ground' and 'groundmass' are used in which ground can be soil, rock, fill, waste, or any mix. Discontinuities denote mechanical discontinuities, except where indicated otherwise. 'Banking' is a term sometimes used to denote layers of intact ground bounded by mechanical discontinuities. Discontinuities are mostly belonging to a 'set' or 'family' of discontinuities in which the discontinuities have the same origin and broadly the same geotechnical characteristics.

\subsection{Weathering terminology}

The terminology on weathering and the resulting weathering products is somewhat confusing. In many literature 'regolith' is used to denote the zone below the Earth surface in which material is affected by or is the 
result of weathering, e.g. weathered rock, loose soils such as fluvial and eolian deposits for which also the term 'transported regolith' may be used, and cemented soils such as hard layers and crusts. Other literature also includes in regolith volcanic deposits as lava flows and volcanic ash, organic material, groundwater-deposited salts, and groundwater itself. The term 'saprolite' may be used for the complete sequence from slightly weathered bedrock to residual soil of a chemically weathered groundmass in a tropical environment (Massey et al. 1989), or only for the completely weathered parts of the bedrock (Wilson 2004). Regolith and saprolite may be used together with the complete weathering sequence denoted regolith but with a subdivision between a top layer named 'residual soil' and the gradual change to bedrock below named saprolite (Singh and Huat 2004). 'Laterite' is used in the literature to describe the 'hard layer' of iron-cemented residual soil resulting from weathering in a tropical environment (Blight 1989), but by others may be used for any red-colored residual soil formed in a tropical environment. In this chapter only the ISO 14689-1:2017 (2017) standard terminology will be used and other terminology avoided as the definitions are ambiguous and rather vague with regard to engineering properties.

\section{Weathering}

Weathering is part of the normal cycle of ground materials on Earth. Rocks are moved up to surface by tectonic forces or extruded by volcanic action. The rocks at surface are weathered due to exposure to the atmosphere, hydrosphere, cryosphere, biosphere, and nuclear radiation that cause disintegration, changes in mineralogy, dissolution, and rock to become soil (Fig. 1). The soil may be eroded by wind, rivers, and glaciers, transported, and finally may end up in lakes or in sea where it becomes sediment. The sediment is buried by subsequent deposits and under an increasing overburden load consolidated, compacted, possibly cemented, heated, melted and coagulated, and/or changed in mineralogy, and becomes rock again. On the other hand, weathering products such as dissolved minerals may be transported by (ground-) water and precipitate at other locations and become cement in-between particles and discontinuities leading to increased strength of intact ground and discontinuities, and may result in hard layers or crusts (section 8).

\subsection{Physical weathering}

Physical weathering results in the breakdown of groundmasses into progressively smaller fragments without changing its components. The main processes in the breakup of ground are differential expansion due to temperature variations, wetting and drying, freezing and thawing, pressures of water and ice in pores between particles in intact ground and in discontinuities, (re-) crystallization pressures, hydration, swelling and shrinkage of minerals due to water absorption, e.g. some clay minerals, grow of plant and tree roots in ground and discontinuities, and animal action. Lightning striking the ground and (bush and underground) fires may also cause reduction of fragments (Knight and Grab 2014; Allison and Bristow 1999). 


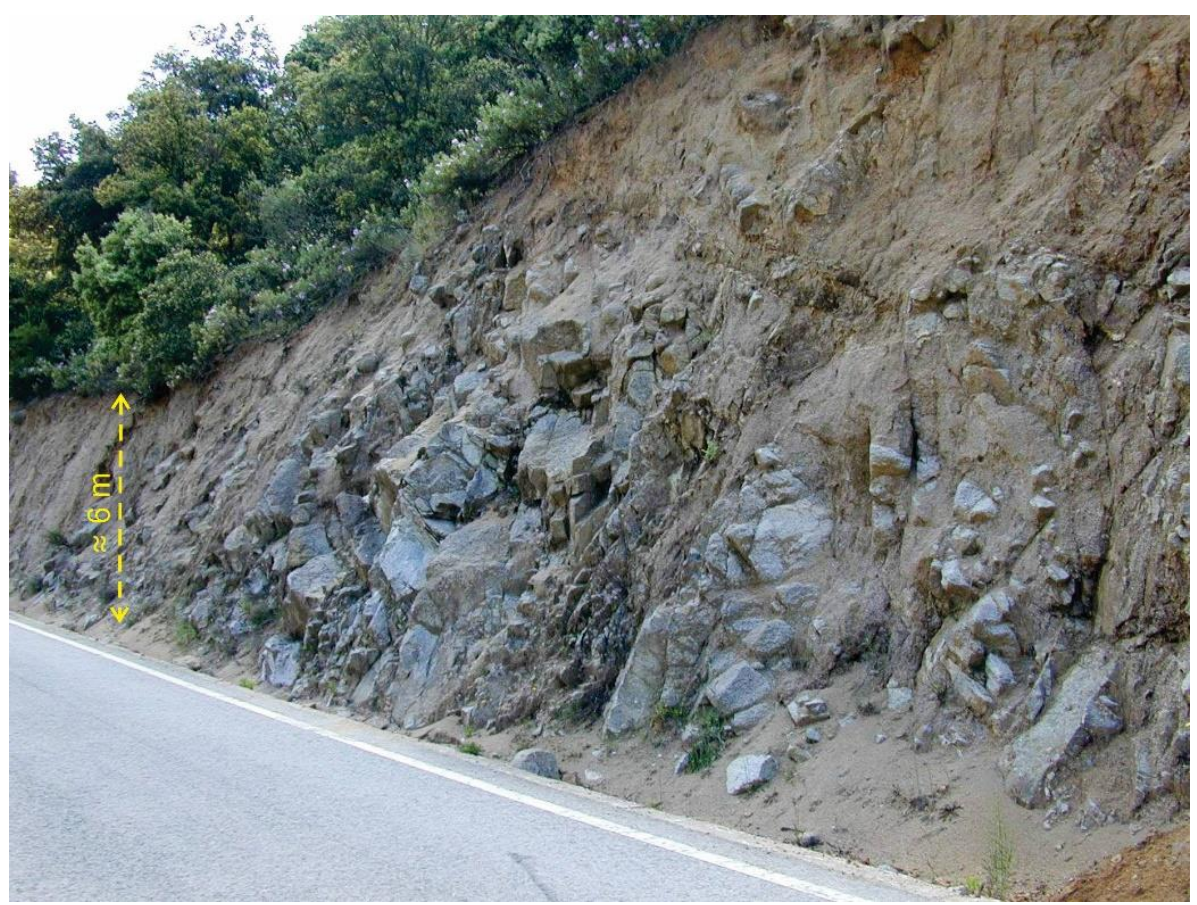

Fig. 1 Exposure of physically and chemically weathered granodiorite (an intrusive, igneous rock comparable to granite); zones of fresh, hard, and strong granodiorite (bluish-grey colored) occur in between zones with granodiorite fallen apart in smaller blocks and zones completely decomposed into loose soil material (brownish colored). Note the general increase of decay upwards to the original topographical surface (vegetated) (Road T710, Falset - Gratallops, Catalunya, Spain; photo courtesy of W. Verwaal 2002)

\subsection{Chemical weathering}

Chemical weathering designates the reactions between minerals and weathering agents and results in decomposition, new forming, and solution of minerals (Fig. 2). Presence of water, groundwater, or air with dissolved or vapor of chemical agents are of major importance as these react with the ground and groundmass material. Some minerals are more susceptible to chemical reactions with weathering agents than other depending on crystal structures and chemical characteristics. For example, silicate minerals based on lattices of a repeating grid of silicon and oxygen weather very slowly if the silicon-oxygen groups are firmly bond directly to each other, e.g. quartz, but weather fast when the oxygen atoms are bond to intermediate atoms as magnesium or iron, e.g. olivine. Other minerals are easily soluble, easily react with oxygen, or with weak carbonic acid (hydrolysis). Temperature is important as chemical reactions are faster under higher temperatures. Therefore, chemical weathering is faster in tropical areas with a warm and humid environment than in an arid polar or mountain environment with low temperatures and little humidity. Biotic influences, induced by living organisms such as plants, bacteria, and worms and the influence of chemicals exerted by living organisms and dissolved in (ground-) water are included in chemical weathering. Chemical weathering may also occur due to man-action, such as polluted groundwater, released acids in mining (Fig. 3), fertilizer dissolved in groundwater, and polluted air and rain, e.g. 'acid rain'. 

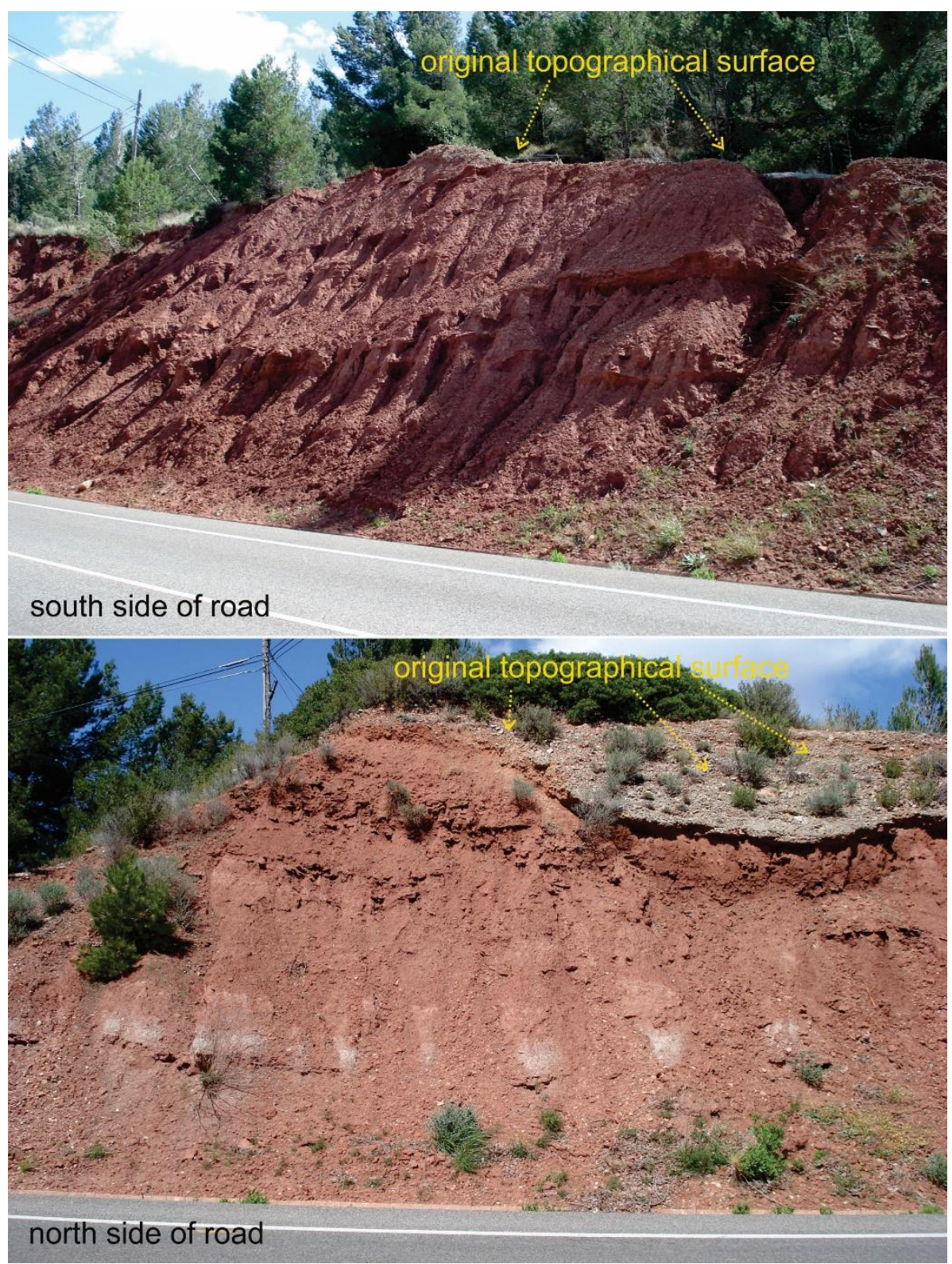

Fig. 2 Road cut slopes excavated in gypsum-cemented siltstone about 5 years after excavation. The slopes were excavated as a plane surface with a slope angle of about $60^{\circ}$. The slopes are instable and eroded due to solution of gypsum after excavation. The north side is less affected than the south side, likely due to more direct sunlight on the north side and the pre-failing wind direction. The protrusive banks in the south side and greyish areas in the north side are layers mainly consisting of gypsum with little silt that are slightly more resistant to solution and erosion (Road C44 near Vandellòs, Catalunya, Spain)

\subsection{Nuclear weathering}

The Earth and any other object in space are subject to a bombardment with different types of radiation consisting of galactic and solar waves and particles from space that may change atom and mineral structures, and disintegrate minerals, ground and groundmasses (Pieters and Noble 2016; Sim et al. 2017). The effect is known as 'space weathering' and the effects are evident on planets and objects in space without atmosphere and magnetic field. On Earth, the Earth atmosphere and the Earth magnetic field stop most radiation from space reaching the Earth surface. Radiation emitted by radio-active materials in the ground of the Earth itself and by man-made nuclear materials have similar effects. The effects of nuclear weathering at or in the Earth surface are likely very small or negligible for engineering compared to weathering by the Earth atmosphere, hydrosphere, cryosphere, and biosphere, except probably for intense radiation by natural nuclear fission and man-made nuclear materials over long periods of times, such as in radio-active waste repositories (section 4.4). 


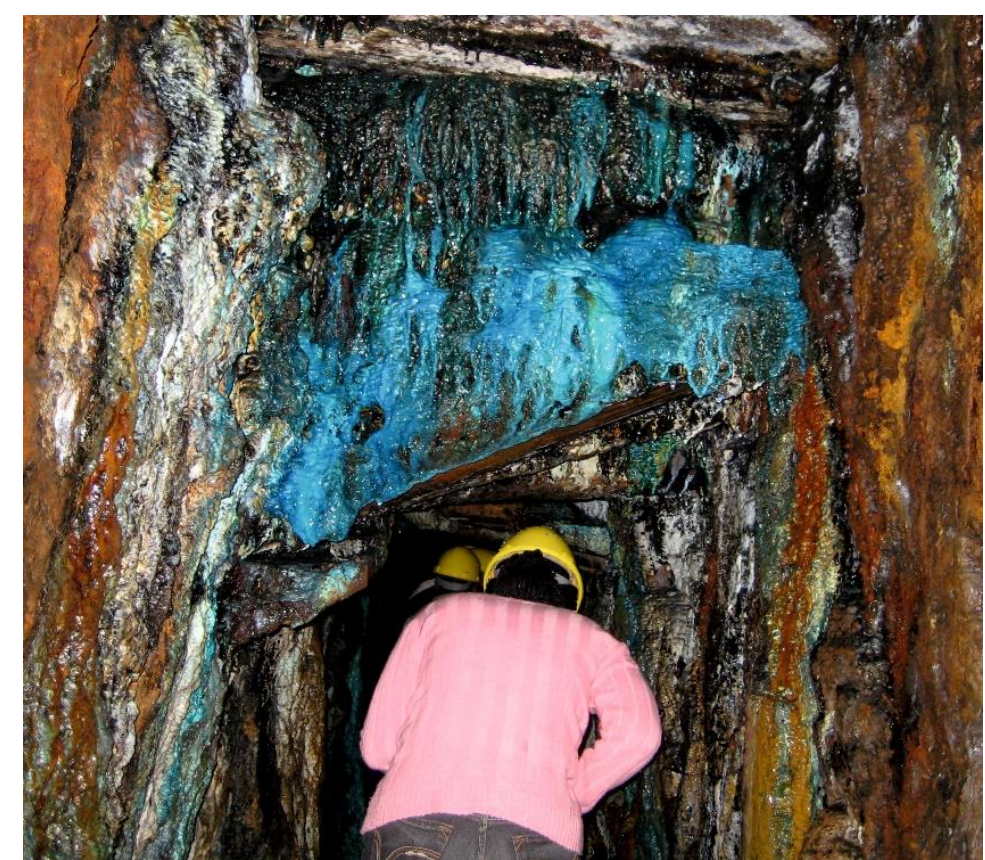

Fig. 3 Acid groundwater causing deterioration of rock mass and steel support in a mine tunnel. Oxidation of metalsulfides by oxygen-rich percolating groundwater caused forming of sulfates and acid water. The blue and white stained areas are sulfates precipitated from seepage water (Gold, silver, copper and lead mine Rammelsberg, Goslar, Harz, Germany; photo courtesy S. Carelsen 2010)

\subsection{Development and weathering of discontinuities}

Discontinuities in groundmasses weather as well. The spacing between mechanical discontinuities at surface is mostly smaller and thus the block size because incipient discontinuities develop into mechanical due to weathering (Fig. 4). The shear strength of discontinuities may reduce due to weathering of the discontinuity wall, solution effects, or forming or change of infill material. For example, in weathered calcareous rock masses containing some clay, it is often found that the walls of the bedding planes are slightly weathered and that a thin clay infill is found in the discontinuities. The infill is the leftover of the weathered rock material. 


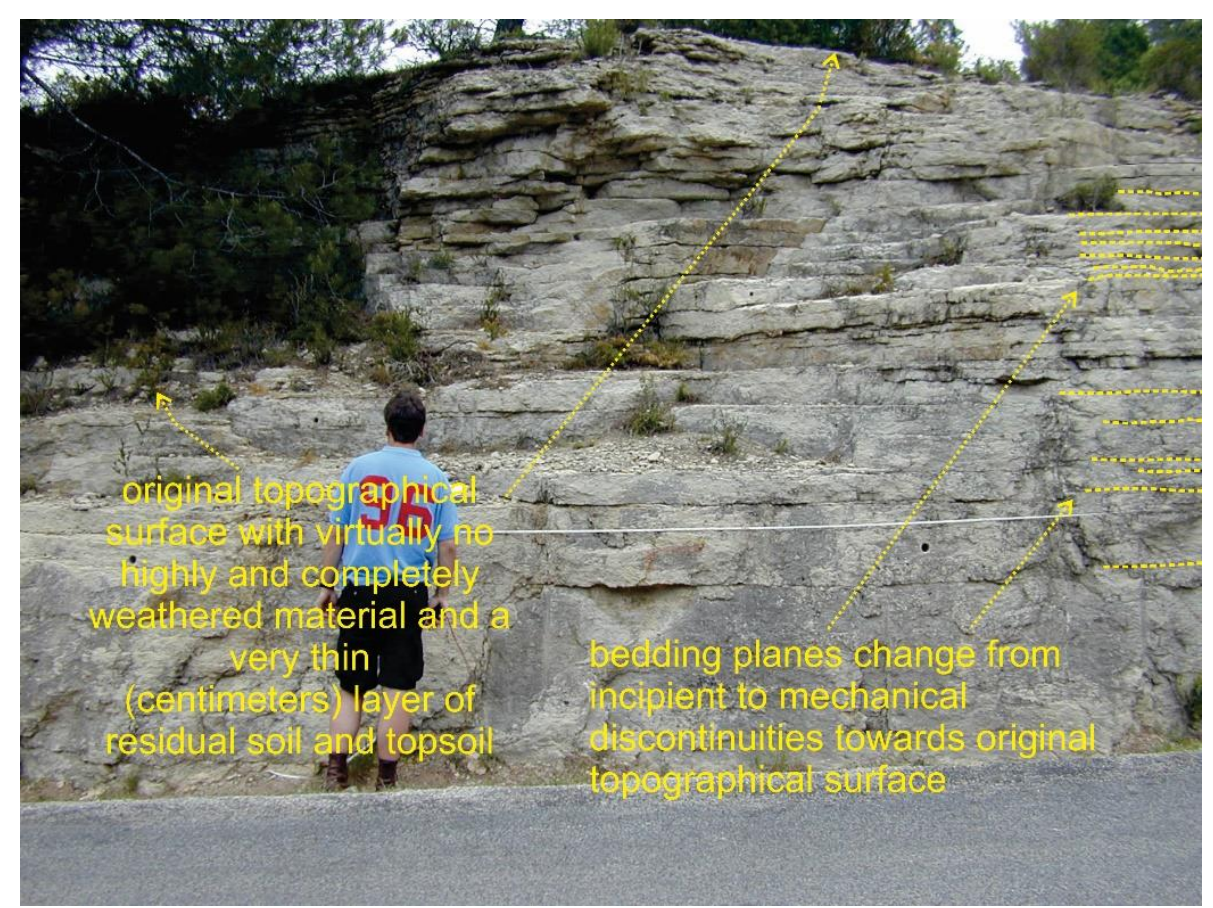

Fig. 4 Decrease of spacing between mechanical discontinuities ('banking' spacing) nearer to the original topographical surface due to weathering of incipient bedding plane discontinuities into mechanical discontinuities. Note the very thin layer of weathered material and topsoil derived by weathering from the limestone rock mass that consists of fairly pure calcareous material (cut slope along road T322-Montroig to Colldejou, $1.3 \mathrm{~km} \mathrm{SE} \mathrm{of}$ Colldejou, Falset, Spain; photo courtesy W. Verwaal 2001)

Mechanical discontinuity sets may develop sequential (Tating et al. 2015). At the onset of weathering first some of the incipient bedding planes develop into mechanical discontinuities, followed at later stages in the weathering process by other sets of discontinuities with different origin. Also, the persistence of discontinuities may extend per set such that in less weathered groundmasses virtually no persistent discontinuities are present, developing over one set being persistent to finally all discontinuities in all sets being persistent in more severely weathered masses. The properties of discontinuities, for example, shear strength, may also be different because of the different duration of weathering since the change from incipient to mechanical discontinuities.

\section{Lithology and types of weathered groundmasses}

Weathering is to a considerable extent depending on the lithology, texture, and structure of the groundmass and groundmass materials. The number of different materials and groundmasses is virtually infinite and therefore also the effects of weathering on groundmasses. However, it is possible to broadly group different groundmasses affected by weathering that show more-or-less comparable effects of weathering.

\subsection{Standard weathering profile}

Throughout the literature and in the standards for geotechnical work mostly a sketch of a typical weathering profile is included, however such profiles are 'idealized' and do not apply to all weathering profiles. Fig. 5 shows the typical weathering profile for a weathered gneiss and schist groundmass in a tropical climate. 


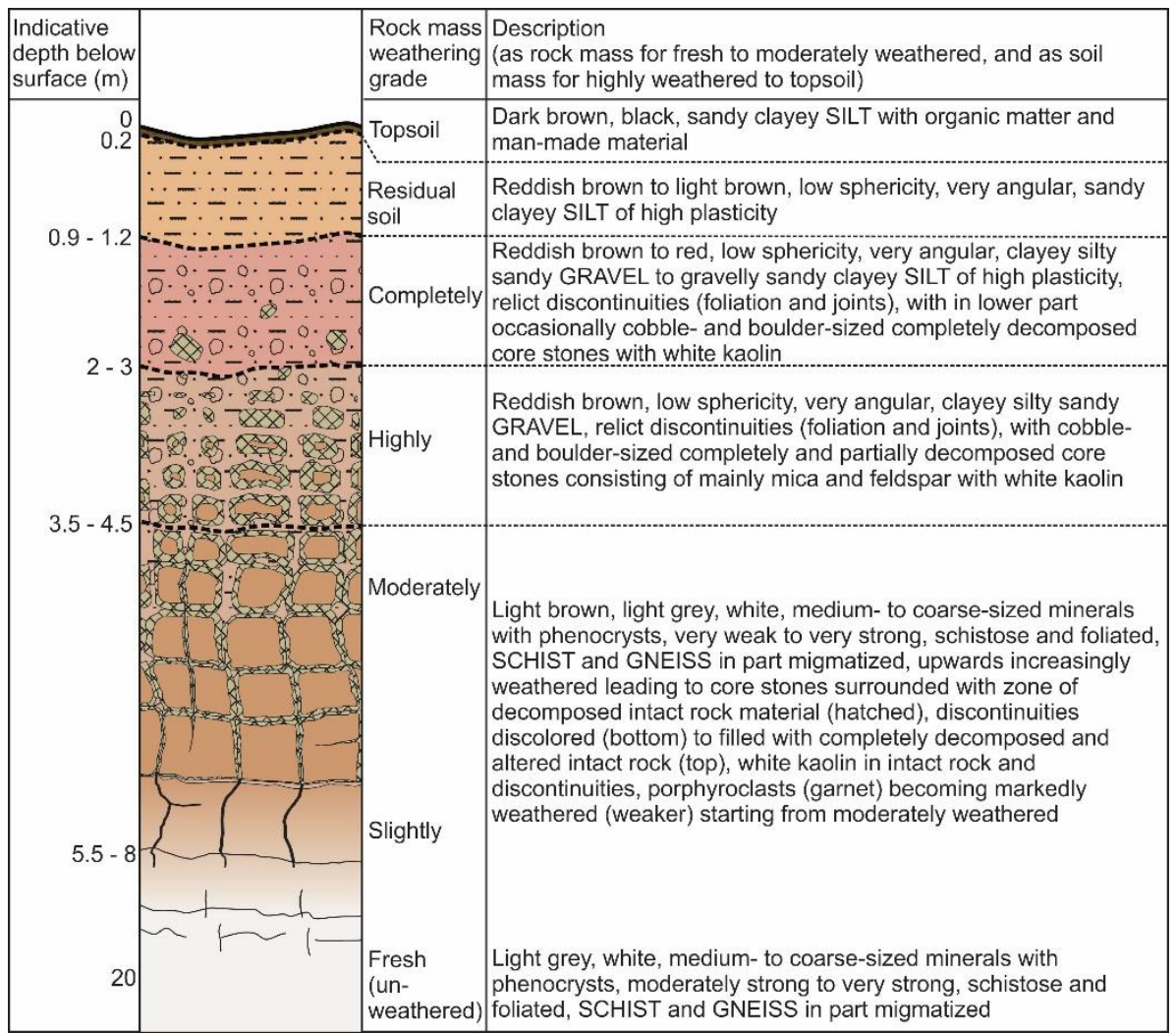

Fig. 5 Example of a weathering profile in a groundmass consisting of weathered gneiss and schist in a tropical climate (Weathering grades follow Table 2 for rock masses) (modified from Tran et al. 2019)

\subsection{Sandstone, intrusive and metamorphic groundmasses}

Sandstones, many intrusives, and many metamorphic groundmasses show a weathering profile similar to those shown in Fig. 5 and Fig. 6. The weathering starts from and via the discontinuities due to percolating groundwater and air in the discontinuities. The discontinuities change progressively from incipient to mechanical discontinuities (section 2.4), become more permeable, thus allow more groundwater and air to percolate, and so allow more and more weathering to occur. Discontinuities become wider, i.e. the aperture increases, because intact ground changes into decomposed intact ground which forms the soil-type discontinuity infill material. Coarser grained, igneous, and metamorphic rocks, and sometimes sandstones may form core stones with a different state of weathering than the surrounding more weathered material, and various sets of discontinuities may have different states of weathering and resulting characteristics due to differences in duration of weathering.

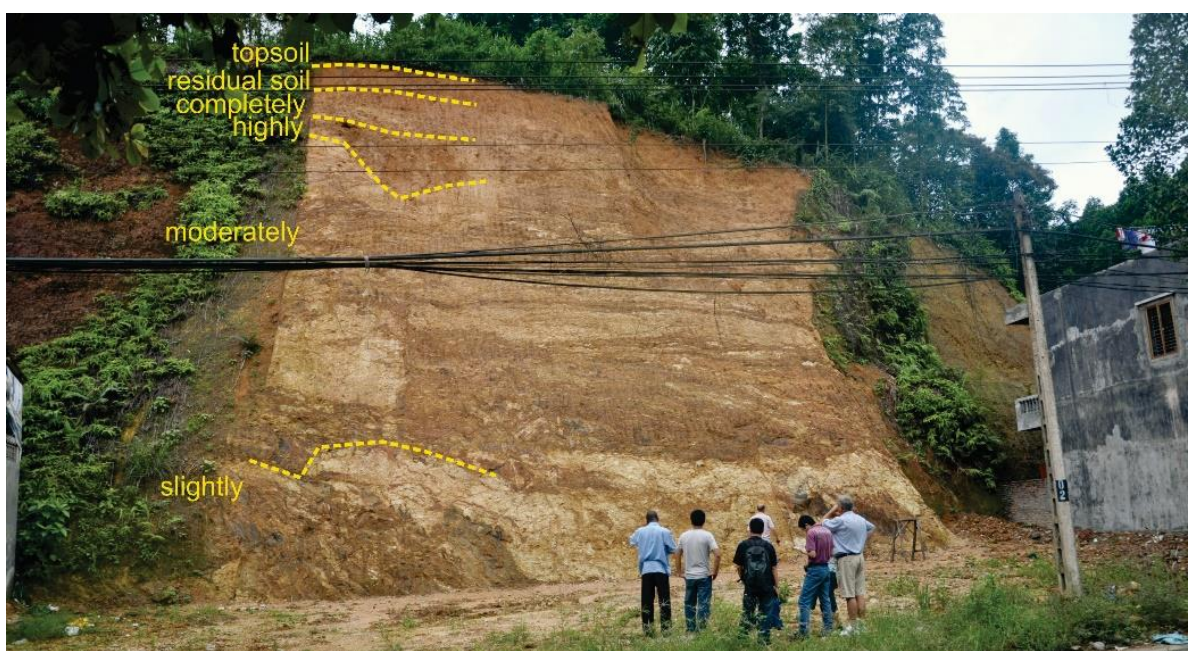

Fig. 6 Weathered cut slope in gneiss and schist in a tropical climate (Weathering grades follow Table 2 for rock masses) (Yên Bái City, Vietnam; photo courtesy D. Alkema, 2010) 


\subsection{Calcareous groundmasses}

Weathered calcareous groundmasses may show a weathering profile as shown in Fig. 5, but generally the amount of weathered material is less as the carbonate for a part or completely dissolves in groundwater and vanishes from the environment. Therefore, completely weathered and residual soil layers formed by weathering of calcareous rock masses are mostly very thin because only the non-dissolvable material, e.g. clay, remains, if the calcareous rock mass contains any non-dissolvable minerals. A very pure calcareous groundmass, i.e. consisting nearly completely of calcareous minerals, does not produce any layers of completely weathered material and residual soil (Fig. 4), and also no infill material in discontinuities. Only the spacing of discontinuities becomes smaller with increasing state of weathering as incipient discontinuities change into mechanical, resulting in smaller block sizes.

\subsection{Varying susceptibility to weathering in one groundmass}

A groundmass with different lithologies with different susceptibilities to weathering may develop a weathering profile in which the less susceptible layers are weathered less than other layers. Consequently, the state of weathering will vary depending on the lithology (Fig. 7).

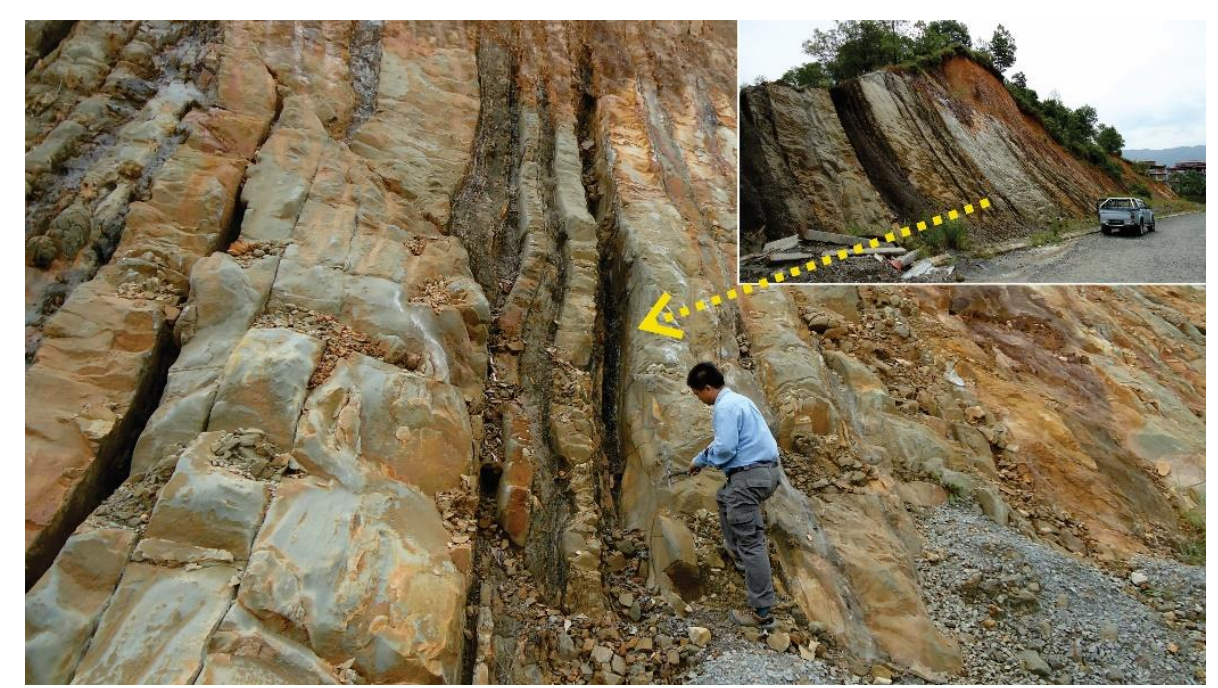

Fig. 7 Different lithologies with different susceptibility to weathering result in groundmasses with layers with different states of weathering. The grey, light-brown sandstone is more resistant to weathering than the darkbrown, black shale that is already completely weathered and partially eroded within five years after excavation giving the inserts in the groundmass (Flysch deposit of sandstone layers mainly consisting of quartz grains, alternating with shale; Kota Kinabalu, Malaysia, 2011)

\subsection{Very thin bedded groundmasses}

Thin-bedded fine-grained sedimentary materials may weather very rapidly directly after exposure due to the influence of atmosphere, hydrosphere, and cryosphere or when stresses change (Miščević and Vlastelica 2014; Huisman 2006). Fig. 8 shows calcareous sedimentary deposits with many incipient bedding planes with very small spacing probably also including some small quantities of organic material. When the groundmass is exposed the mas destresses and becomes subject to temperature and humidity variations. Incipient sedimentary bedding planes become then mechanical discontinuities and rapidly within a couple of years, the groundmass falls apart. 


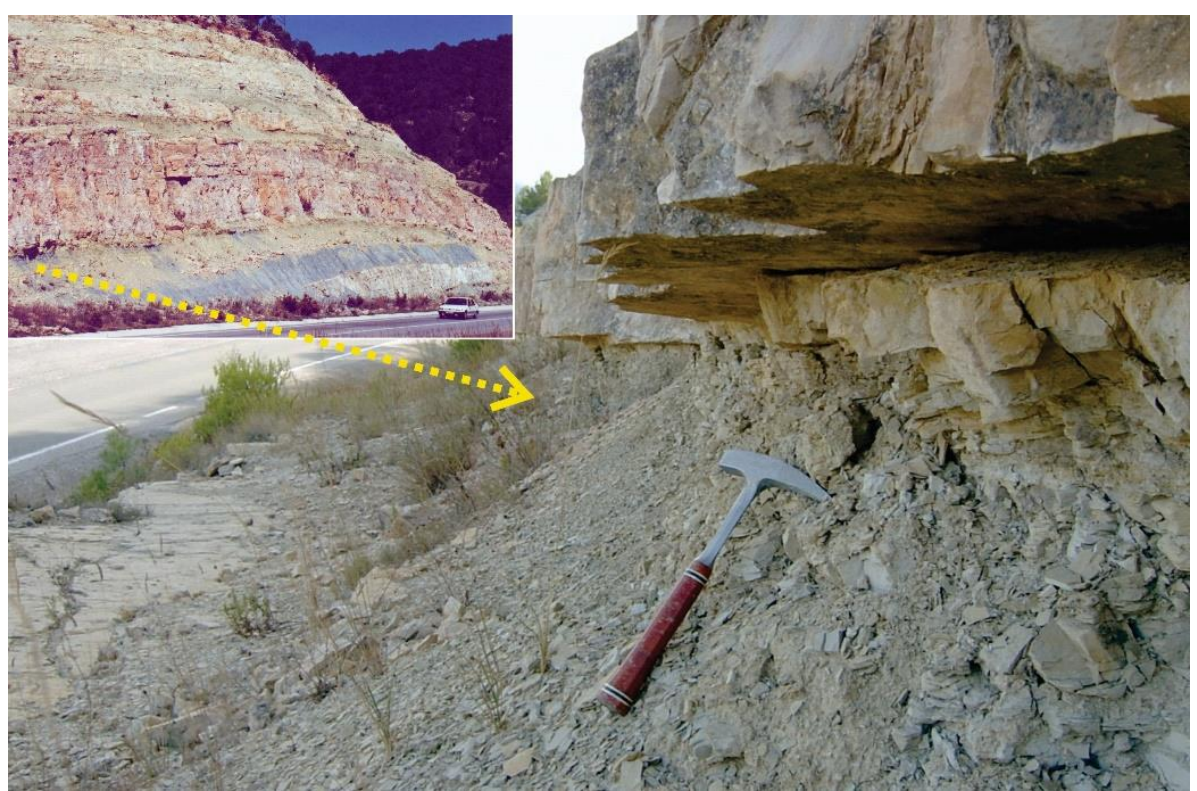

Fig. 8 Thin-bedded sedimentary mudstone and claystone with angular more-or-less equidimensional rock blocks of some $20 \mathrm{~cm}$ fall apart in rounded very small flaky particles of millimeter size due to stress relief and weathering within a couple of years after exposure in a warm temperate to semi-arid Mediterranean climate. The insert photo shows layers of bluish-greenish mudstone and claystone alternating with pinkish dolomite layers. (length hammer about $30 \mathrm{~cm}$ ) (Hostal Slope, along N420 road, km 846, Falset, Spain; large photo courtesy M. Huisman 2004)

\subsection{Disking in borehole cores - weathering of borehole cores}

A similar feature as with thin-bedded sedimentary rocks may occur in borehole cores. Newly-formed mechanical discontinuities split the borehole core in 'disks' when arriving at surface. The process is described by the term 'disking' or 'discing'. Various processes and mechanisms sometimes acting together are responsible. Mud- and claystones and shales show a disking effect in which closely spaced incipient bedding planes become mechanical discontinuities due to stress relief and temperature and humidity changes. Presence of swelling minerals is also of influence (Ohta 2001). Disking may be time dependent and cores directly after drilling may show little disking but this increases with time (Hoek and Brown 2018) which is very similar to the weathering as described in section 3.5. The effect of disking is mostly more severe for borehole cores from larger depth (Stacey 1982). Core disking may also be due to the existence of (highly anisotropic) in-situ horizontal stresses in relation to the tensile strength of the material even if the material in-situ is unfractured and not bedded, for example, disking of granite without any form of incipient bedding, layering, or fracturing (Lim and Martin 2010).

\subsection{Groundmasses containing easily dissolvable minerals; gypsum and salt}

Anhydrite, gypsum, and salts are generally very easily dissolving in (ground-) water. This causes that the complete groundmass with these minerals or part of it vanishes with the water and when the soluble minerals forms the cement between the particles in the groundmass the groundmass develops into a loose uncemented soil (Fig. 2) (Huisman et al. 2006). Salt dissolves virtually instantly after excavation at contact with water, i.e. first rain, while anhydrite and gypsum may dissolve a in a couple of years in a temperate or humid climate. Therefore, exposed groundmasses with anhydrite, gypsum or salts exist in arid climates only.

\subsection{Karstic groundmasses}

Karst is weathering by solution in carbonate, anhydrite, gypsum, or salt containing groundmasses where part of the groundmass is dissolved and removed by groundwater (Pesendorfer and Loew 2004; Schmitz and Schroeder 2009). The process starts with dissolving material along discontinuities due to percolating groundwater resulting in small cavities and holes along discontinuities. In strong rock masses with not too fast dissolving minerals, e.g. calcareous minerals, these may grow into caves, sometimes of a size allowing underground streams and rivers, such as the river Lesse in Belgium (Caves Han-sur-Lesse 2018). In weaker groundmasses solution pipes often infilled with materials from above, may have penetrated deeply into the calcareous groundmass (Price et al. 2009). 


\subsection{Volcanic groundmasses}

Lava and ash are formed relatively rapidly as these cool very fast resulting in small minerals of which many are unstable under surface conditions (Yokota and Iwamatsu 2000). Some coagulated lavas, as for example, some basalts, have a very low permeability that prevents minerals to be in contact with weathering agents as water, but ash has a high permeability, thus many options for contact between unstable ash minerals and agents, and weathering of ash is very fast. Minerals in volcanic ashes disintegrate quite rapidly, dissolve, or weather into clay minerals (James et al. 2000; Yokota and Iwamatsu 2000). Weathering of volcanic deposits may be 30 times faster than weathering of granite or shale under the same conditions (Dosseto et al. 2012). The rapid weathering produces the very fertile agricultural soils in volcanic areas.

\subsection{Groundmasses with sulfides; oxidation of sulfides}

Weathering by oxidation of sulfides such as pyrite is influenced by bacteria, air, and oxygen-rich water that cause the sulfides to decompose into an oxide and sulfuric acid. The oxide minerals are mostly less strong or have a different volume than the original sulfide minerals and therefore, reduce the mechanical strength parameters of the ground. The acid may be aggressive to the groundmass, engineering structures, and the environment (Fig. 3) (Brattli and Broch 1995; Oyama and Chigira 2000). Sulfur and sulfides such as pyrite, may spontaneously combust if in contact with oxygen-rich air, leading to underground fires if igniting nearby combustible materials (section 3.11) (Wu et al. 2006).

\subsection{Organic groundmasses; coal and peat fires and peat weathering}

Combustion and fires of coal and peat are also a form of weathering (Kuenzer and Stracher 2012). These may occur in coal seams and peat layers that are in contact with oxygen-rich air. Combustion may start at surface exposures and can run underground for kilometers if faults or subsidence cracks allow fresh air to reach the coal or peat and eject exhaust gasses. Poor mining practices, uncontrolled exploitation, or natural spontaneous combustion of coal may be the onset of coal fires and bush fires may be the onset of peat fires. Oxidation of sulfur and sulfides present in the coal or surrounding layers may start or accelerate the fire (section 3.10) (Didier et al. 2008). Underground coal fires are notoriously difficult to stop and sometimes may burn for many tens to thousands of years (Krajick 2005). The burning process converts the coal and peat in gasses with a large volume reduction of the original seams and layers. In the organic layers but also in surrounding non-organic layers minerals may change or fall apart due to the heat and heating may fracture intact ground, leading to a geotechnically less strong ground. The inverse may also happen if minerals in surrounding layers are cooked or baked such that the layers become stronger. The ground remaining after the fire may have cavities partially or completely filled by collapsed overlying ground, open discontinuities, and major subsidence at surface can occur. The layers between the layer the fire was in to surface may have irregular boundaries and subsidence cracks.

Weathering of peat is due to water or air with oxygen percolating through peat layers that cause (bio-) oxidation and disintegration of organic material in the peat. The peat undergoes a large reduction in volume and land subsidence is the result, such as in Venice, Italy (Gambolati et al. 2005), Ireland, Finland, The Netherlands, and many other countries.

\subsection{Poisonous fluids and gasses}

Particular geological conditions may cause weathering that forms (highly poisonous) arsenic groundwater, for example, in parts of India and Bangladesh, China, South and North America, and Eastern Europe (Ghosh and Singh 2009; BGS Arsenic 2001; Welch et al. 2000; VanDerwerker et al. 2018). Although the origin of the arsenic and the process how it ends up in the groundwater are not known in all detail in all areas, it is likely that in Bangladesh and India, the arsenic stems from coal seams, micas, pyrite-bearing shale, or gold deposits, that are weathered, eroded, transported, and became soil deposits at another location. These later deposits are in contact with the groundwater in which the arsenic is released. Possibly anaerobic conditions, bacterial or man-action, such as contamination of the groundwater with fertilizer, may be of influence in releasing the arsenic from the soil deposits into the groundwater. Another very dangerous weathering process is the release of deadly quantities of hydrogen sulfide gas from reactions between methane released by coal and bacterial sulphate reduction of anhydrite (Alborz Service Tunnel, Iran, Wenner and Wannenmacher 2009). 


\subsection{Man-made groundmasses; fills and waste dumps}

Man-made groundmasses such as dumped or dredged fills for land reclamation weather if the fill or dump materials are prone to weathering. Municipal solid waste dumps may weather due to decay of materials, often forming gas and fluids and leaving cavities in the mass (Machado et al. 2008). Groundwater below and around waste dumps may become polluted by a whole series of chemicals of which many are unfriendly for the environment, poisonous, aggressive for engineering structures, or may react with surrounding groundmasses.

\section{Weathering rate and depth of weathering}

The rate of weathering, i.e. the weathering per time unit, is highly variable and strongly depends on the type of groundmass, environment, climate, and local circumstances, such as erosion, the accessibility of the groundmass for (ground ) water and air, and dissolved minerals in (ground-) water and vapor in air. Nuclear radiation may also have an influence on weathering rates. Under some conditions weathering may have a significant impact on engineering structures within a few years whereas in other no influence is observed in centuries (Huisman et al. 2006; Hack et al. 2003; Tating et al. 2013; Tran et al. 2019; Cabria 2015). Consequently, the same holds for the weathering depth into the groundmass. In humid and warm environments, in-situ weathering from surface may go down to tens and often more than one hundred meters below surface (Lumb 1983; Qi et al. 2009; Fookes 1997). In dry climates, however, the in-situ weathered zone is often just a few decimeters or meters deep. The depth of the weathered zone is less where weathered material is removed by erosion (section 4.2) or by solution into (ground-) water.

\subsection{Environment and climate}

The environment and climate have a major influence on rate and depth of weathering. In a tropical humid climate chemical weathering is dominant and minerals fall apart very rapidly under influence of chemical reactions. In more temperate climates physical weathering becomes dominant, whereas in arid polar or dry mountain climates physical weathering will be virtually the sole mechanism of weathering (Lamp et al. 2017). Further important factors are the amount of sunlight on the groundmass, wind force, and prevailing wind direction. The sunlight and wind allow for fast drying of the ground after rainfall and hence reduce chemical reactions that involve water and thus reduce the chemical weathering rates. Larger differences in temperature between day and night and over the seasons and alternating wetting and drying due to cyclic rainfall increase physical weathering. Soluble (e.g. carbonate, anhydrite, gypsum, and salts) materials fall apart or dissolve faster in a wet climate than in a drier climate.

\subsection{Erosion}

Erosion predominantly occurs at the Earth surface and is generally less relevant in underground works. However, underground water flows, including water leaking from sewage and water mains, may transport soil or infill materials. Erosion by itself may lead also to effects similar as those in weathering, for example, the saltation of sand that reduces particle size of sand grains and creating dust particles in wind (Shao et al. 1993). Grinding of rock blocks over the bedrock in rivers and glaciers reducing block size of a moving block, and also fracturing, loosening, and unlashing rock blocks and particles from the bedrock ('plucking') by moving water, ice or wind are other examples (Singh et al. 2011; Anderson and Anderson 2010).

Weathered materials often form a good insulation of the underlying groundmass from the influence of the atmosphere, hydrosphere, cryosphere, and often also biosphere. This de-accelerate weathering, slows further weathering in depth, and when the layer of weathered material is thick enough effectively stops further weathering. Inversely, erosion causes the insulation to be removed, exposing the groundmass to the environment, accelerate weathering, and allow further progressive weathering in depth of new fresh ground. Erosion thus increases the rate of weathering of the underlying material (Huisman et al. 2011; Tating et al. 2019).

\subsection{Accessibility of groundmass for weathering agents}

Weathering of soil-type material mostly progresses through intact material and discontinuities, if present. The weathering agents, such as water and air, percolate through the pores and channels between pores in intact ground, and through discontinuities. The permeability of intact rock-type material is normally quite low and therefore weathering of rock masses mostly starts from the discontinuities through which the weathering agents circulate and develops further into the intact rock material from the discontinuities. Causing, for example, a gradual 
decrease in strength of intact rock towards the discontinuity. In many groundmasses discontinuities give thus the access to the groundmass for weathering agents, and the number of permeable discontinuities determines for a considerable extent the rate of weathering in rock masses. Discontinuities, such as faults, with percolating groundwater may exist at any depth below surface and groundmasses at large depth of thousands of meters may be subject to active in-situ weathering (Katongo 2005).

Man-made influences such as the damage caused by the tools and means used for making an excavation may allow faster and deeper weathering. The excavation method may create fractures, widen existing discontinuities, and change incipient into mechanical discontinuities, collectively denoted 'backbreak', that allow water and air to infiltrate easier and deeper into the groundmass (Fig. 9) (Hack et al. 2003).

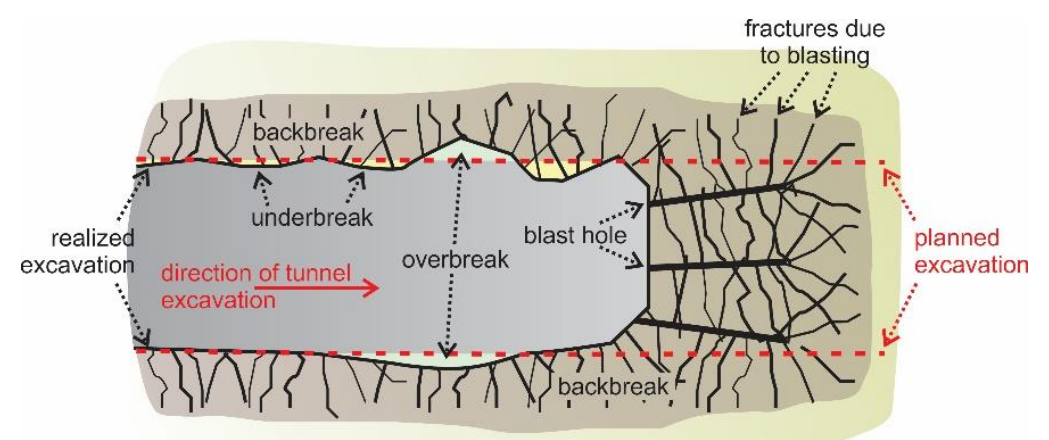

Fig. 9 Discontinuities in a groundmass due to blasting and present as backbreak in the walls, roof, and floor of a tunnel

Generally, more backbreak is caused when higher energy levels are used in shorter timespans, i.e. blasting gives a high energy peak with many backbreak fractures, while scouring by a river creates an exposure virtually without any backbreak as energy is applied over many hundreds or thousands of years. Table 1 illustrates the damaging influence of excavation methods in use for surface and underground excavations with quantitative factors for the damage. The factors are correction factors applied to groundmass properties.

Table 1 Excavation damage ('backbreak') factors for groundmasses

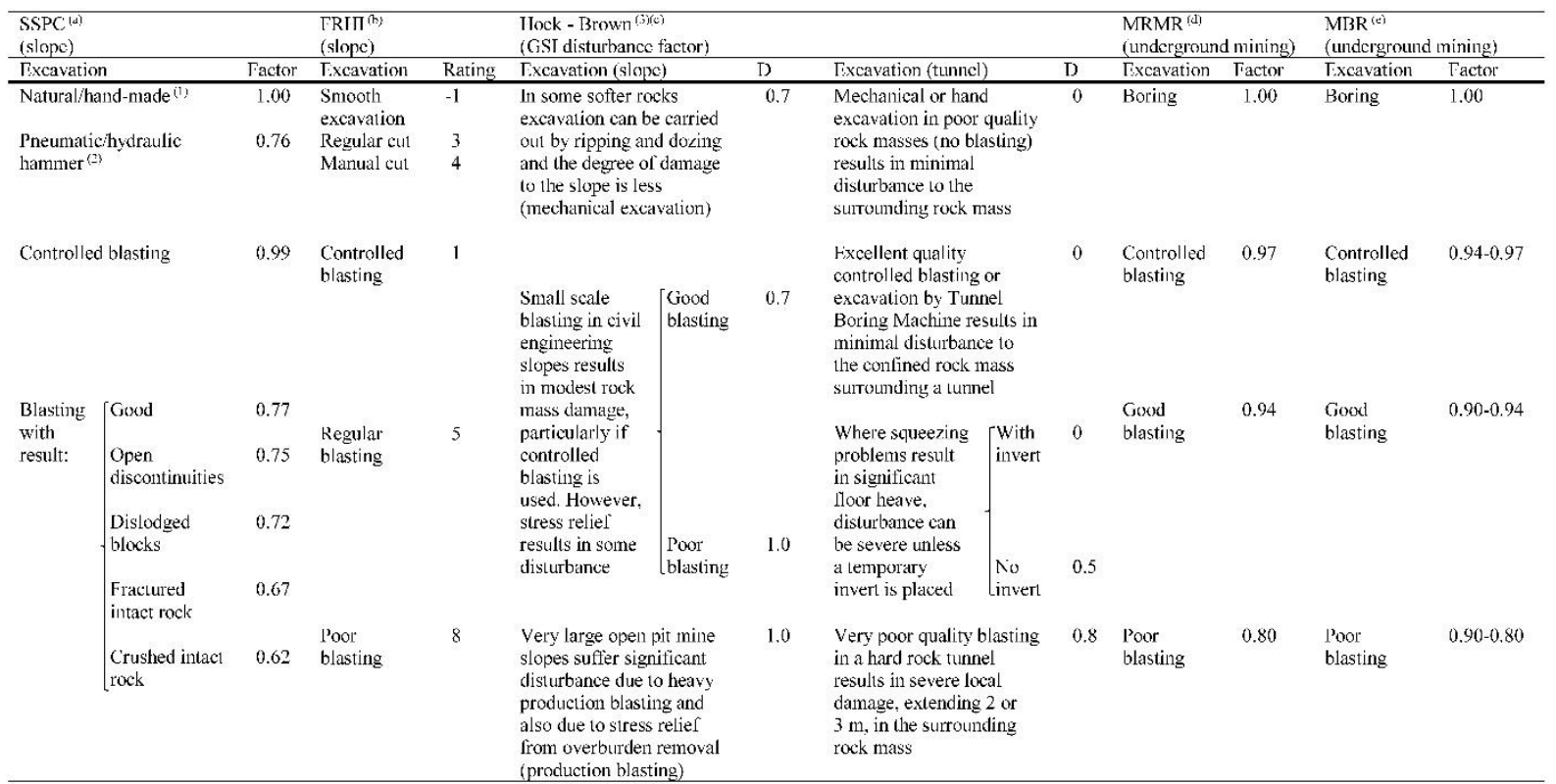

Notes: SSPC, MRMR and MBR factors range from 1.00 for negligible damage to 0.62 respectively 0.80 for maximum damage, FRHI is expressed as point rating from -1 for no damage to 8 for maximum damage, GSI disturbance factor ranges from 0 for undisturbed to 1.0 for maximum disturbance. (1) Care should be taken that discontinuities due to stress relief are not considered excavation damage. (2) This value is based on hammer sizes up to $5 \mathrm{~m}$ length with a diameter of $0.2 \mathrm{~m}$. (3) The description of D is referenced with example photographs of excavation damage. Data from: (a) Hack et al. (2003) (b) Singh (2004) (c) Rocscience (2011) \& Hoek and Brown (2018) (d) Laubscher and Jakubec (2001) (e) Cummings et al. (1984). 


\subsection{Nuclear radiation effects}

Few research is done on the influence of nuclear radiation on groundmasses on Earth. In facilities for longterm storage of radioactive nuclear waste, degradation of the surrounding groundmass, brines, and groundwater is a subject of limited research (Lainé et al. 2017; Lumpkin et al. 2014; Soppe and Prij 1994). Changes of atoms and minerals under influence of radiation is also occurring in natural nuclear reactions (Oklo reactor; Meshik 2009; Bracke et al. 2001). Weathering rates due to nuclear radiation are likely very low compared to the rates under other influences, but may be of importance for stability of rooms, tunnels and shafts guaranteeing access to underground radioactive-waste repositories over very long timespans of tens of thousands of years.

\subsection{Local environment and engineering influence}

Weathering is strongly dependent on local conditions, such as surface run-off water, snow and ice, vegetation and animals, chemicals in groundwater, salt-containing water and air, and man-made action. Water run-off over and through the near surface of an exposure may erode weathered surface material and expose new fresh ground to the environment progressing weathering of the fresh ground. Surface run-off water will have a larger influence on a slope in a groundmass with a small block size than with a larger block size because smaller blocks are more easily flushed away by run-off water. Steeper slopes are less affected than less steep slopes because the water runs over faster and water less easily penetrates the groundmass. Snow and ice may block seepage from discontinuities where discontinuities are outcropping at an exposure, which may lead to water pressures in the pores and discontinuities, causing intact material to break, existing discontinuities to widen, and incipient discontinuities to become mechanical. In situ in the groundmass, frozen water that expands because ice has a larger volume than water, may cause the same changes.

Roots of trees and other vegetation may grow into the ground and discontinuities resulting in fractures in intact ground, changing incipient into mechanical discontinuities, root wedging that dislodges blocks, opening of discontinuities, and subsequently access for (more) water and air and thus more and faster weathering. Vegetation is normally not present in underground excavations; however, small plants may start growing in lighted tunnels. Actions by other living species such as fungus, bacteria, and larger animals as worms and other burying animals, may influence weathering in surface but also in underground excavations by for example, making burrows that allow water and air to penetrate the groundmass more easily. Vegetation and animals may also excrete chemicals that attack the ground material causing degradation.

Ground and surface water may be polluted such as water seeping from sewages, landfills, waste dumps, ore mines and tailings, or be polluted with fertilizer. Natural groundwater in some grounds may also be aggressive, for example, acid water corroding the tunnels of the London Underground (Rainey and Rosenbaum 1989) or water around the tunnel for the Niagara Tunnel project, Canada (Hughes et al. 2007). Air pollution has a negative effect on all ground, and also on natural and non-natural construction and building materials by reactions between the minerals in the ground or construction materials and the chemicals in the polluted air (e.g. 'acid rain') (Doehne and Price 2010). This causes chemical weathering but may also cause physical weathering due to precipitation and crystallization in pores and discontinuities of chemicals from polluted air or newly-formed chemicals.

Salt-water and salt containing vapor may penetrate the groundmass and discontinuities (Cabria 2015; Wellman and Wilson 1965; Mottershead 1989; Rodriguez-Navarro et al. 1999; Ruiz-Agudo et al. 2007). The salt may directly react with ground material and cause degradation of the ground material, or salt may precipitate in pores and discontinuities and expansion of salt crystals causes breaking of intact ground, widen existing discontinuities, and change incipient into mechanical discontinuities. The salt may originate from salty capillary groundwater, polluted air, or seawater spray. Salt in the atmosphere from seawater spray may be present up to many tens of kilometers from the coast.

\section{Description of weathered groundmasses}

Weathering is gradational and to be able to use gradational features of weathering in engineering normally the weathered groundmass is characterized and divided into different layers with similar weathering characteristics defined by a range of characteristics or parameters significant for engineering applications (Dearman 1995). Note that this only describes the weathering as is at the time of characterization and does not include the future changes due to weathering. Future weathering is discussed in section 7. 


\subsection{Weathering features important in engineering}

Each type of groundmass weathering has a specific impact on engineering. Uniformly weathered layers following, for example, Fig. 5, give the least difficulties with forecasting the geotechnical properties in the subsurface, while properties of irregular layers with different states of weathering or layers resulting from different susceptibilities to weathering are far more difficult to forecast in detail. Often the division in states of weathering for engineering purposes is based on the following characteristics (Price 1995):

- Effectively unweathered. Weathering has not influenced the groundmass to an extent that weathering must be considered in design of engineering works.

- Significantly weathered. The design should incorporate some limited influence of weathering on engineering properties, for example, weathering of discontinuities may have reduced shear strength of discontinuities.

- Severely weathered. Weathering must be considered otherwise the engineering applications will not be stable or functional.

- For rock masses: sufficient of the rock material in a rock mass is decayed to the geotechnical condition of a soil to make the mass behave as a soil-type mass geotechnically.

\subsection{Standard schemes for weathering description}

The above is used to define standard descriptions for the division of a weathered groundmass in different layers with different states of weathering, and thus with different impact on engineering design. Many standard schemes have been proposed, some fairly simple, such as in Table 2, or following more elaborate schemes as in Fig. 10. A simple scheme is easy to use but may not always be suitable. The more elaborate schemes apply better to various groundmasses and materials, but may be (too) complex and may be misunderstood (Price et al. 2009).

Table 2 Weathering description and characterization of intact rock and rock mass (ISO 14689-1:2017)

\begin{tabular}{|c|c|c|c|c|}
\hline \multirow{2}{*}{\multicolumn{2}{|c|}{ INTACT ROCK }} & \multirow{2}{*}{\multicolumn{3}{|c|}{ ROCKMASS }} \\
\hline & & & & \\
\hline Term & Description & Term & Description & Grade \\
\hline Fresh & $\begin{array}{l}\text { No visible sign of weathering/alteration } \\
\text { of the rock material. }\end{array}$ & Fresh & $\begin{array}{l}\text { No visible sign of rock material weathering; } \\
\text { perhaps slight discoloration on major } \\
\text { discontinuity surfaces. }\end{array}$ & 0 \\
\hline \multirow[t]{2}{*}{ Discolored } & $\begin{array}{l}\text { The color of the original fresh rock } \\
\text { material is changed and is evidence of } \\
\text { weathering/alteration. The degree of } \\
\text { change from the original color should be }\end{array}$ & $\begin{array}{l}\text { Slightly } \\
\text { weathered }\end{array}$ & $\begin{array}{l}\text { Discoloration indicates weathering of rock } \\
\text { material and discontinuity surfaces. }\end{array}$ & 1 \\
\hline & $\begin{array}{l}\text { indicated. If the color change is } \\
\text { confined to particular mineral } \\
\text { constituents, this should be mentioned. }\end{array}$ & $\begin{array}{l}\text { Moderately } \\
\text { weathered }\end{array}$ & $\begin{array}{l}\text { Less than half of the rock material is } \\
\text { decomposed or disintegrated. Fresh or } \\
\text { discolored rock is present either as a } \\
\text { continuous framework or as core stones. }\end{array}$ & 2 \\
\hline \multirow[t]{2}{*}{ Disintegrated } & $\begin{array}{l}\text { The rock material is broken up by } \\
\text { physical weathering, so that bonding } \\
\text { between grains is lost and the rock is } \\
\text { weathered/altered towards the condition } \\
\text { of a soil in which the original material } \\
\text { fabric is still intact. The rock material is }\end{array}$ & $\begin{array}{l}\text { Highly } \\
\text { weathered }\end{array}$ & $\begin{array}{l}\text { More than half of the rock material is } \\
\text { decomposed or disintegrated. Fresh or } \\
\text { discolored rock is present either as a } \\
\text { discontinuous framework or as core stones. }\end{array}$ & 3 \\
\hline & $\begin{array}{l}\text { friable but the mineral grains are not } \\
\text { decomposed. }\end{array}$ & $\begin{array}{l}\text { Completely } \\
\text { weathered }\end{array}$ & $\begin{array}{l}\text { All rock material is decomposed and/or } \\
\text { disintegrated to soil. The original mass } \\
\text { structure is still largely intact. }\end{array}$ & 4 \\
\hline Decomposed & $\begin{array}{l}\text { The rock material is weathered by the } \\
\text { chemical alteration of the mineral grains } \\
\text { to the condition of a soil in which the } \\
\text { original material fabric is still intact; } \\
\text { some or all of the mineral grains are } \\
\text { decomposed. }\end{array}$ & $\begin{array}{l}\text { Residual } \\
\text { soil }\end{array}$ & $\begin{array}{l}\text { All rock material is converted to soil. The } \\
\text { mass structure and material fabric are } \\
\text { destroyed. There is a large change in } \\
\text { volume, but the soil has not been } \\
\text { significantly transported. }\end{array}$ & 5 \\
\hline
\end{tabular}




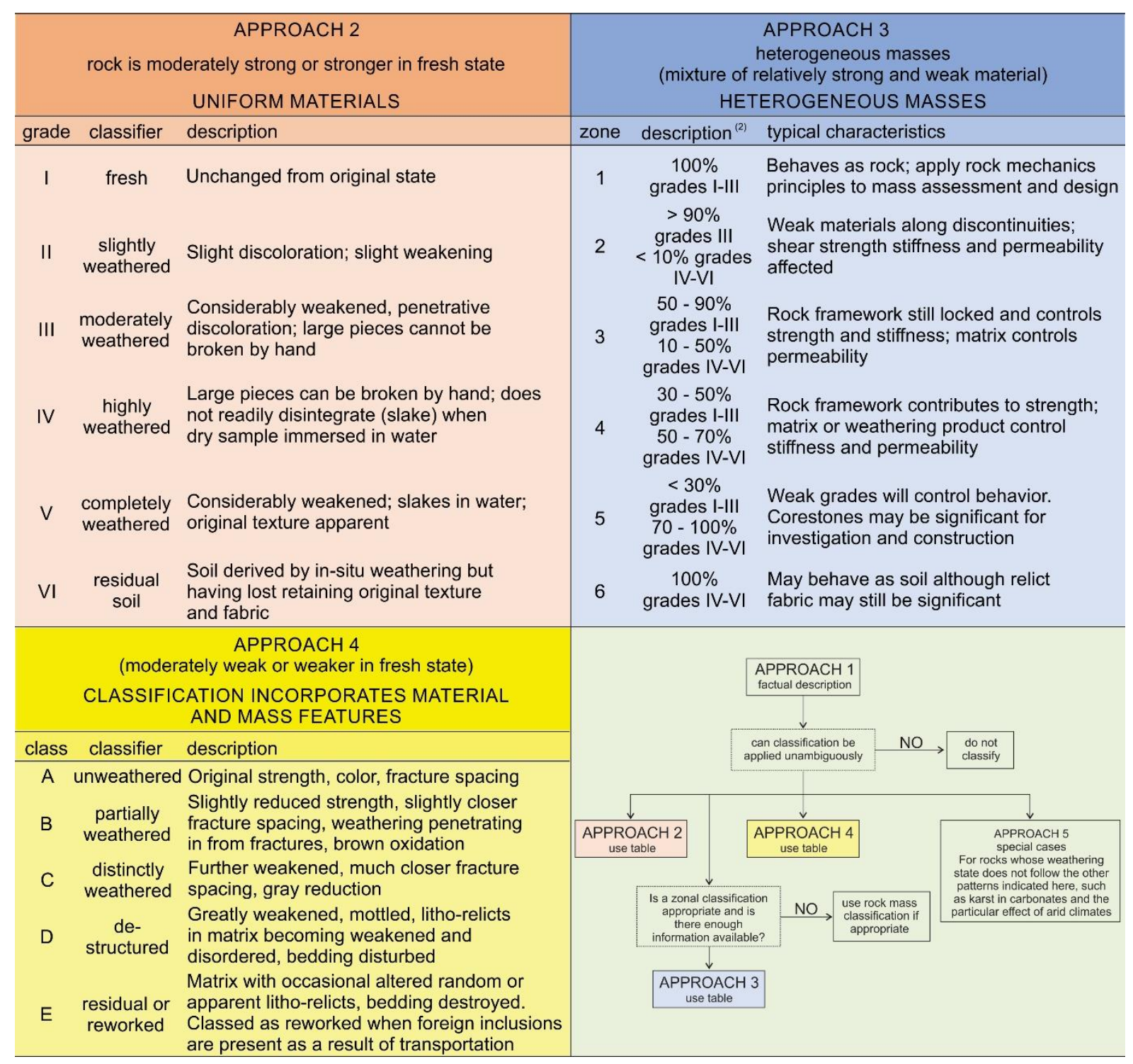

Fig. 10 Description state of weathering (BS 5930:1999)

\section{Quantitative influence of weathering on geotechnical properties}

Table 3 shows examples of properties of intact ground and groundmasses indicating how ground properties change with increasing grade of weathering. The table shows the considerable changes in material properties as a consequence of weathering. 
Table 3 Examples of differences in engineering properties due to weathering

\begin{tabular}{|c|c|c|c|c|c|c|c|c|c|c|c|}
\hline Grade ${ }^{\{1\}}$ & $\begin{array}{l}\text { In-situ } \\
\text { unit } \\
\text { weight }\end{array}$ & Porosity & Permeability & $\begin{array}{l}\text { Unconfined } \\
\text { compressive } \\
\text { strength }\end{array}$ & $\begin{array}{l}\text { Unconfined } \\
\text { tensile } \\
\text { strength }\end{array}$ & $\begin{array}{l}\text { Static } \\
\text { deformation } \\
\text { modulus }\end{array}$ & $\begin{array}{l}\text { Seismic veloc } \\
\text { Longitudinal } \\
\text { wave }\end{array}$ & $\begin{array}{l}\text { y } \\
\text { Shear } \\
\text { wave }\end{array}$ & $\begin{array}{l}\text { Schmidt } \\
\text { hammer } \\
\text { number }\end{array}$ & $\begin{array}{l}\text { Rock mass } \\
\text { friction }\end{array}$ & $\begin{array}{l}\text { Rock mass } \\
\text { cohesion }\end{array}$ \\
\hline & $\mathrm{kN} / \mathrm{m}^{3}$ & $\%$ & $\mathrm{~cm} / \mathrm{s}$ & $\mathrm{MPa}$ & $\mathrm{MPa}$ & GPa & $\mathrm{m} / \mathrm{s}$ & $\mathrm{m} / \mathrm{s}$ & - & degrees & $\mathrm{kPa}$ \\
\hline \multicolumn{12}{|c|}{ Dolorite ${ }^{(a)}$} \\
\hline $0-1$ & 28.0 & 0.4 & & 170 & 45 & 16.5 & 4,500 & & 64 & & \\
\hline 2 & 27.6 & 0.5 & & 122 & 27 & 3.3 & 3,250 & & 53 & & \\
\hline 3 & 27.0 & 1 & & 71 & 13 & & 2,150 & & 45 & & \\
\hline 4 & 26.2 & 3.2 & & 41 & 7 & & 1,600 & & 25 & & \\
\hline \multicolumn{12}{|c|}{ Granodiorite } \\
\hline 0 & 26.3 & 1.5 & & 138 & & 33 & 4,359 & 2,567 & & 47 & 17 \\
\hline 1 & 25.9 & 4.6 & & 79 & & 15 & 2,057 & 1,693 & & 46 & 16 \\
\hline 2 & 25.4 & 1.9 & & 41 & & 10 & 1,693 & 1,111 & & 38 & 14 \\
\hline 3 & 24.0 & 5.7 & & 32 & & 4.9 & 973 & & & 17 & 8 \\
\hline 4 & 19.8 & 24 & & 0.1 & & 0.008 & & & & 6 & 3 \\
\hline \multirow{2}{*}{\multicolumn{12}{|c|}{ Basalt $^{(c)}$}} \\
\hline & & & & & & & & & & & \\
\hline $\begin{array}{l}0 \\
1\end{array}$ & $26.1^{(2)}$ & 2 & $1 \times 10^{-8}$ & 110 & 9 & 58 & & & & & \\
\hline 2 & $25.7^{(2)}$ & 4 & $1 \times 10^{-8}$ & 75 & 7 & 48 & & & & & \\
\hline 3 & $23.0^{(2)}$ & 10 & $5 \times 10^{-8}$ & 30 & 3 & 23 & & & & & \\
\hline 4 & $21.6^{(2)}$ & 36 & $1 \times 10^{-5}$ & 8 & & 10 & & & & & \\
\hline 5 & $16.5^{(2)}$ & 45 & $1 \times 10^{-4}$ & & & & & & & & \\
\hline \multicolumn{12}{|c|}{ Sandstone ${ }^{(d)}$} \\
\hline 0 & $25.0^{(3)}$ & & & 101 & & & & & & & \\
\hline 1 & $26.3^{\{3\}}$ & & & 58 & & & & & & & \\
\hline 2 & $23.6^{(3)}$ & & & 21 & & & & & & & \\
\hline 3 & $23.8^{\{3\}}$ & & & 8 & & & & & & & \\
\hline \multicolumn{12}{|c|}{ Gneiss \& schist ${ }^{(4)(e)}$} \\
\hline 4 & 16.8 & 53 & $3 \times 10^{-5}$ & 0.36 & & & & & & 32 & 5 \\
\hline 5 & 16.3 & 54 & $1 \times 10^{-5}$ & 0.29 & & & & & & 21 & 22 \\
\hline
\end{tabular}

Notes: (1) Grade follows the classification in Table 2 for rock masses. (2) Dry density (3) Values may be influenced by precipitation of iron in particular weathering grades. (4) Values for two years after excavation. Data: (a) Dolerite at Stirling Castle, UK (Price 2000) (b) Granodiorite data from Krank (1980), except rock mass friction and cohesion. Granodiorite rock mass friction and cohesion from slope back analysis in Granodiorite in the Falset area, Spain, from Hack (1998) (c) Tuğrul (2004) (d) Tating et al. (2013) (e) Tran et al. (2019).

Quantification of the grades of weathering in terms of the reduction of geotechnical properties of rock masses is shown in Fig. 11. The graph is based on data from various authors and from different rock types and rock masses. The influence of weathering is quite clear in the decrease of intact rock strength over the complete sequence from fresh to completely weathered rock masses and for the decrease in discontinuity spacing and condition of discontinuities (determining the shear strength) down to moderately weathered rock masses. The influence of weathering on spacing and condition of discontinuities de-accelerate or invert from moderately to highly weathered which may be attributed to cementation processes in discontinuities often happening in higher grades of weathering.

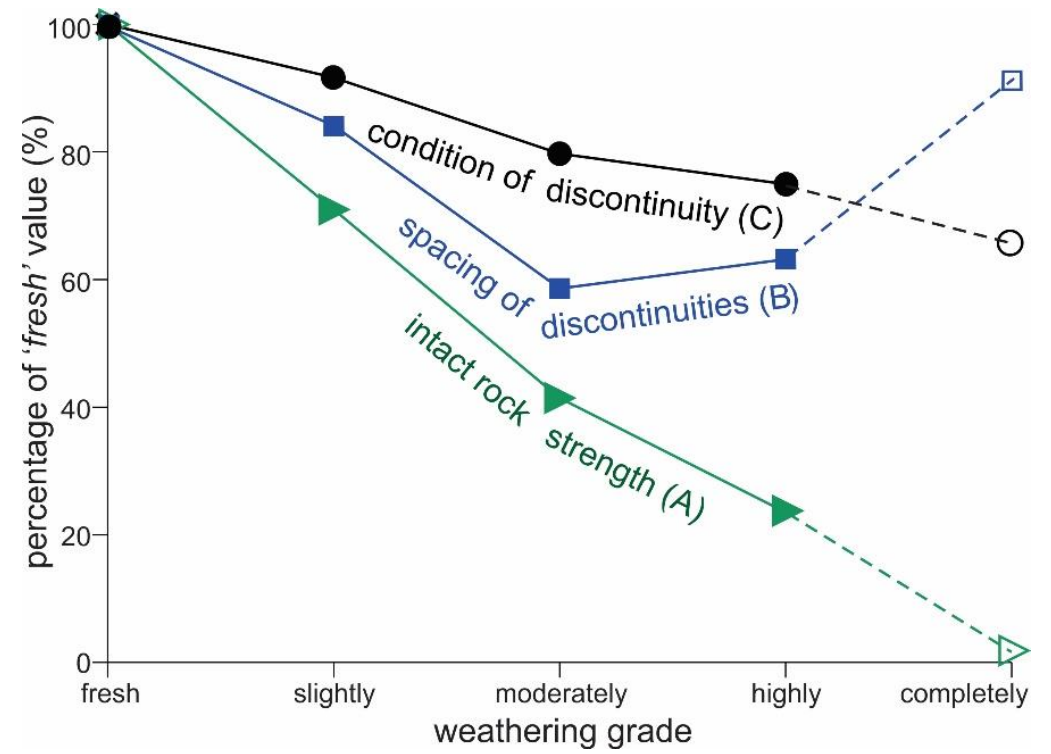

Notes: Data averaged after normalization with values for fresh equal $100 \%$. Standard deviation around 15 to $23 \%$ p (percent point) for slightly through highly weathered; data for completely weathered are few and average not reliable. Weathering grade refers to rock mass weathering following Table 2. 'Spacing of discontinuities' based on rock block size and form following Taylor (1980) in Hack et al. (2003) or on discontinuity spacing. 'Condition of discontinuity' (determining the shear strength) following sliding criterion (Hack et al. 2003) or friction and cohesion properties for discontinuities. Data: A: 1, 5, 6, 7 \& 10; B: 2, 3, 4 \& 5; C: 5, 8 \& 9. (1) Begonha and Sequeira Braga (2002) (2) Ehlen (1999) (3) Ehlen (2002) (4) GCO (1990) (5) Hack and Price (1997) (6) Marques et al. (2010) (7) Pickles (2005) (8) Reißmüller (1997) (9) Snee (2008) (10) Tuğrul (2004).

Fig. 11 Influence of weathering on intact rock and rock mass properties 
Quantification of grades of weathering in terms of the reduction of geotechnical properties of a groundmass have been done by various authors (Hack and Price 1997; Bieniawski 1989). Table 4 gives an example in which the factors are based on the weathering at surface of a wide range of rock masses such as limestone, sandstone, shale, granodiorite, and slate in the Mediterranean climate of northeast Spain. The factors in the table are multiplied with the geotechnical property to give the weathered property in a particular grade of weathering.

Table 4 Adjustment factors (WE) for different geotechnical properties of a rock mass (Hack and Price 1997; Hack et al. 2003)

\begin{tabular}{lllllll}
\hline Grade ${ }^{(1)}$ & Description & $\begin{array}{l}\text { Intact } \\
\text { rock } \\
\text { strength }\end{array}$ & $\begin{array}{l}\text { Overall } \\
\text { spacing of } \\
\text { disconti- } \\
\text { nuities }\end{array}$ & $\begin{array}{l}\text { Overall } \\
\text { condition } \\
\text { of disconti- } \\
\text { nuities }\end{array}$ & $\begin{array}{l}\text { Rock mass } \\
\text { friction }\end{array}$ & $\begin{array}{l}\text { Rock mass } \\
\text { cohesion }\end{array}$ \\
\hline 0 & Fresh & 1.00 & 1.00 & 1.00 & 1.00 & 1.00 \\
1 & Slightly & 0.88 & 0.93 & 1.00 & 0.95 & 0.96 \\
2 & Moderately & 0.70 & 0.89 & 0.99 & 0.90 & 0.91 \\
3 & Highly & 0.35 & 0.63 & 0.89 & 0.59 & 0.64 \\
$4^{(2)}$ & Completely & 0.02 & 0.55 & 0.80 & 0.31 & 0.38 \\
\hline
\end{tabular}

Notes: (1) Grade follows the classification in Table 2 for rock masses. (2) 'Completely weathered' is assessed in granodiorite only.

\section{Susceptibility to weathering}

To guarantee the safe and sound design for the whole lifetime of an engineering structure it is important to know what the geotechnical properties of the groundmass are going to be at the end of the lifetime, i.e. 'what is the susceptibility to weathering of the groundmass?' Comparing the condition of the groundmass in similar exposures but with different excavation dates is the most common method to establish susceptibility to weathering. Preferably the exposures should be on short distance from each other and from the construction site. The weathering processes should be the same and be the same as those going to act around and influence the future engineering structure, hence, geomorphological and environmental setting should be the same.

Published quantitative data on future changes in properties due to weathering and the rate of weathering for engineering purposes are only sparsely known. Laboratory studies are not very reliable for forecasting in-situ weathering rates as these depend on the local circumstances and environment, and the tests are limited in groundmass volume and time (section 9.1). How groundmasses deteriorate over long (geological) periods over large areas (landscape development) is reasonably well investigated by geological, geomorphological, denudation, and soil forming studies (section 7.1). The influence of weathering on intact rock used as building material or gravestones has been extensively studied in-situ and rates for loss of material due to weathering have been established by many researchers ('tomb-or gravestone geology', section 7.2). However, few studies are published for 50 to 100-year time spans over areas from tens up to a couple of hundreds of meters, the typical engineering lifetime and size (Fig. 12). This is understandable, as in-situ testing is virtually impossible while local variations and inhomogeneity make geological methodologies complicated and unreliable. Some rock mass classification systems have factors that quantitatively assess the future weathering (section 7.3) and some recent studies to weathering rates are presented in section 7.4. 


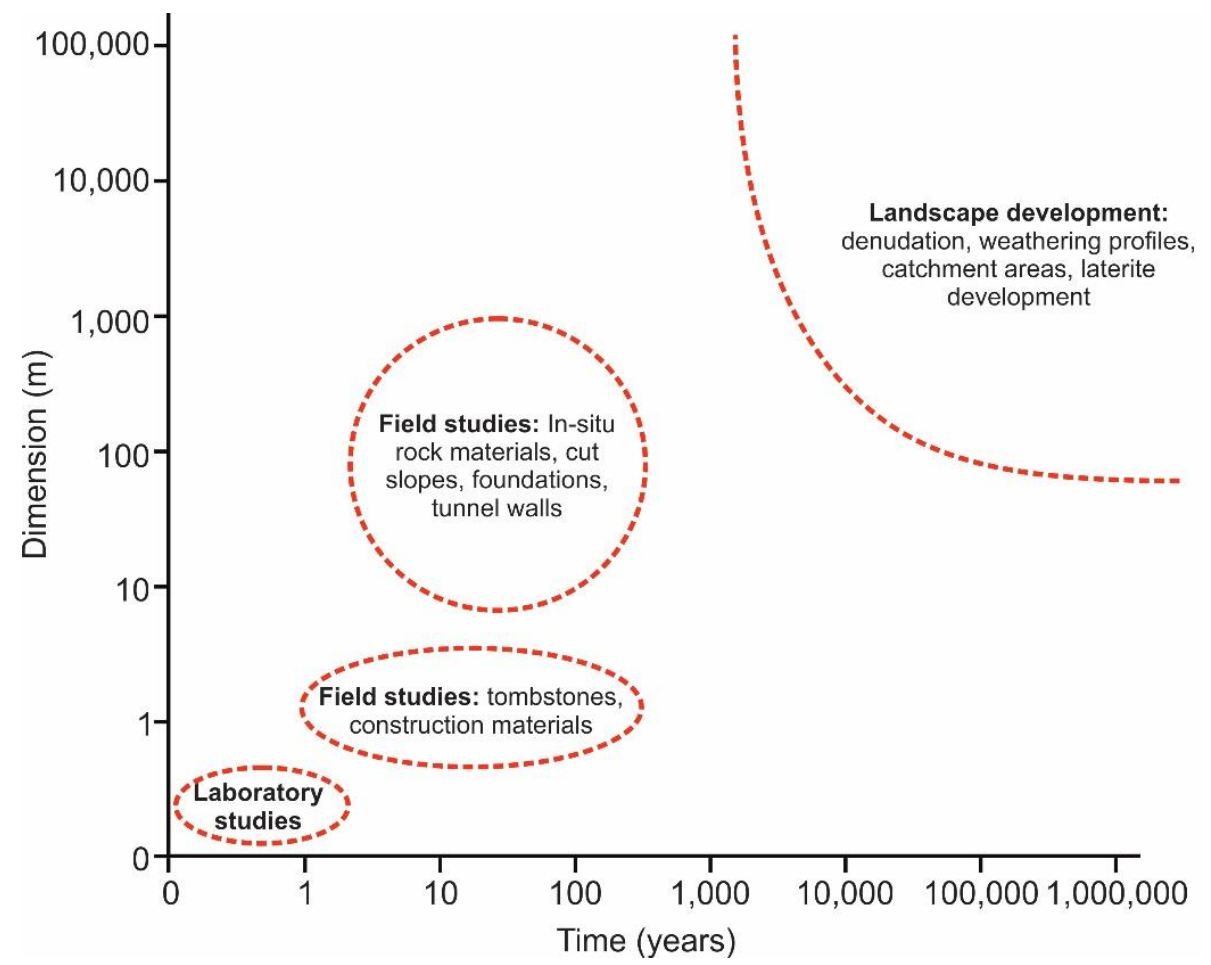

Fig. 12 Research to weathering and erosion as function of space and time (modified from Huisman 2006)

\subsection{Loss of material, denudation studies over long (geological) timespans}

Loss of material due to weathering resulting in denudation over relatively large areas and long (geological) timespans is extensively studied as it may reveal data over past climates and $\mathrm{CO}_{2}$ presence in the atmosphere, hydrosphere, and cryosphere (Ahnert 1994; Lebedeva et al. 2010). Denudation is mostly established by measuring the differences in quantities of chemical elements in rivers and streams flowing into and out of an area. If more leaves than flows into the area, the differences are a measure for the loss of material. Denudation over large areas and large timespans is dependent on active tectonic uplift and mountain forming, vegetation, and influences by man, such as land use and (de-) forestation. It should be realized that the climate and environment may have undergone major changes during the periods over which the denudation rates are established. Table 5 lists various denudation rates for different lithologies under different present-day climates.

Table 5 Examples of denudation rates

\begin{tabular}{|c|c|c|c|c|}
\hline Lithology & Area & Denudation rate r(1) $^{(1)}$ & \multicolumn{2}{|c|}{ Present-day climate $^{(2)}$} \\
\hline Granitic (a) $^{(a)}$ & Chile & $0.02-0.07$ & $\mathrm{Bsk} / \mathrm{Csa}$ & Semi-arid, Mediterranean \\
\hline Granitic $^{(b)}$ & Boulder, USA & 0.022 & $\mathrm{Dfc} / \mathrm{Dfd}$ & Boreal, mountain \\
\hline $\begin{array}{l}\text { Granulites, migmatites, gneisses, } \\
\text { schists, phyllites, granitoids, and } \\
\text { alluvial beds }{ }^{\text {(c) }}\end{array}$ & $\begin{array}{l}\text { Ambato range, Sierras } \\
\text { Pampeanas, Argentina }\end{array}$ & $0.038-0.12$ & $\begin{array}{l}\text { Bsk/Bsh/ } \\
\text { Cwb }\end{array}$ & Arid/warm temperate \\
\hline Mica schist, phyllite ${ }^{(d)}$ & $\begin{array}{l}\text { Sierra de las Estancias, } \\
\text { Betic Cordillera, Spain }\end{array}$ & 0.034 & Bsk & Semi-arid, mountain \\
\hline Mica schist, phyllite ${ }^{(d)}$ & $\begin{array}{l}\text { Sierra de los Filabres, } \\
\text { Betic Cordillera, Spain }\end{array}$ & 0.054 & $\begin{array}{l}\mathrm{Csa} / \mathrm{Csb} / \\
\text { Bsk }\end{array}$ & $\begin{array}{l}\text { Humid to semi-arid, } \\
\text { mountain }\end{array}$ \\
\hline Mica schist ${ }^{(d)}$ & $\begin{array}{l}\text { Sierra Cabrera, Betic } \\
\text { Cordillera, Spain }\end{array}$ & 0.164 & Bsk/Bwh & Semi-arid, mountain \\
\hline $\begin{array}{l}\text { Granitic, carbonate and quartz-bearing } \\
\text { metasedimentary rocks }(\mathrm{e})\end{array}$ & $\begin{array}{l}\text { Ganges, Northern } \\
\text { Himalayas }\end{array}$ & 0.5 & $\mathrm{Cwa} / \mathrm{Cwb}$ & $\begin{array}{l}\text { Humid; warm temperate, } \\
\text { mountain }\end{array}$ \\
\hline Quaternary sediments ${ }^{(\mathrm{e})}$ & Ganges, main stem & 0.17 & Cwa & Humid, warm temperate \\
\hline Quaternary sediments ${ }^{(e)}$ & $\begin{array}{l}\text { Ganges, southern } \\
\text { tributaries }\end{array}$ & 0.03 & Cwa/Aw & $\begin{array}{l}\text { Humid, warm } \\
\text { temperate/tropical }\end{array}$ \\
\hline Basalt $^{(f)}$ & Paraná, Brazil & 0.006 & Csb & Humid, warm temperate \\
\hline
\end{tabular}

Notes: (1) Rates based on ${ }^{10} \mathrm{Be}$ cosmogenic radionuclide (CRN) analysis, if reported. (2) Climate according Kottek and Rubel (2017). Data: (a) Vázquez et al. (2016) (b) Dethier and Lazarus (2006) (c) Nóbile et al. (2017) (d) Schoonejans et al. (2016); Vanacker et al. (2014) (e) Rahaman et al. (2017) (f) Da Conceição et al. (2015).

\subsection{Loss of material, tombstone geology studies over short timespans}

Loss of material of various intact rock types over short timespans and tested on relatively small samples is done mainly on building and construction stones (Fookes et al. 1988; Selby 1993; Doehne and Price 2010; Morgan 
2016; Winkler 1986). The amount of intact rock material lost under influence of weathering in a temperate climate on a forested slope in Japan came to $1.3 \% / \mathrm{yr}$ for tuff material, 0.1 for limestone, 0.025 for crystalline schist, and $0.01 \% / y r$ for granite. The samples were exposed directly at the Earth surface (Matsukura and Hirose 2000). Trudgill et al. (2001) measured the loss of material of exterior building stones of St Paul's Cathedral in London which consist mainly out of limestone, over a period of 20 years and measured a reduction of 0.01 to $0.07 \mathrm{~mm} / \mathrm{yr}$. The results are influenced by air pollution (i.e. $\mathrm{SO}_{2}$ ) in London that decreased over the measuring period. Tombstone geology has also been used to establish changes in environment, climate, and air pollution (Meierding 1993). Feddema and Meierding (1987) report values of 0.001 to $0.067 \mathrm{~mm} / \mathrm{yr}$ for carbonate building stones in areas with varying quantities of air pollution, and Meierding (1993) established weathering rates of over 0.03 $\mathrm{mm} / \mathrm{yr}$ for carbonate rocks in heavily air-polluted areas in the USA. The striking similarity in order of magnitude between rates for loss of material of small building stones over short timespans and loss of material over large areas over long timespans is remarkable (section 7.1).

\subsection{Laubscher's geotechnical susceptibility to weathering factors}

Weathering rates for rock masses in underground excavations and its influence on rock mass geotechnical properties and classification ratings are shown in Table 6 (Laubscher and Jakubec 2001). The percentages in Table $\mathbf{6}$ are multiplication factors which are multiplied with the rock mass ratings calculated following Laubscher and Jakubec (2001), e.g. the rock mass rating is reduced to $54 \%$ of the original rating without susceptibility to weathering if a rock mass is expected to weather from fresh to completely weathered within a half year, whereas it is reduced to $62 \%$ if that happens in more than 4 years. It should be noted that conditions in underground excavations are considerably different and in general with less variation than the conditions influencing weathering at surface.

Table 6 Adjustment values for susceptibility to weathering for classification of stability of underground excavations in mining (modified from Laubscher and Jakubec 2001)

\begin{tabular}{|c|c|c|c|c|c|c|}
\hline \multirow{3}{*}{$\begin{array}{l}\text { Expected } \\
\text { grade of future } \\
\text { weathering }\end{array}$} & \multirow[t]{3}{*}{ Description } & \multicolumn{5}{|c|}{$\begin{array}{l}\text { Percentage adjustment for a rock mass } \\
\text { weathered from fresh to indicated grade; after: }\end{array}$} \\
\hline & & $1 / 2$ year & 1 year & 2 year & 3 year & $\geq 4$ year \\
\hline & & \multicolumn{5}{|l|}{$\%$} \\
\hline 0 & Fresh & 100 & 100 & 100 & 100 & 100 \\
\hline 1 & Slightly & 88 & 90 & 92 & 94 & 96 \\
\hline 2 & Moderately & 82 & 84 & 86 & 88 & 90 \\
\hline 3 & Highly & 70 & 72 & 74 & 76 & 78 \\
\hline 4 & Completely & 54 & 56 & 58 & 60 & 62 \\
\hline 5 & Residual soil & 30 & 32 & 34 & 36 & 38 \\
\hline
\end{tabular}

Notes: The adjustment is applied to the rating for the stability of the underground excavation of Laubscher's rock mass classification to predict the future stability. (1) The grades of rock mass weathering follow Table 2 for rock masses.

\subsection{Geotechnical rate of weathering}

The influence of weathering on geotechnical properties over timespans from 50 to 100 years is thought to be expressed by a logarithmic decrease of properties with time (Huisman 2006; Tating et al. 2013; Ruxton 1968; Selby 1980; Colman 1981; Hachinohe et al. 2000; Utili and Crosta 2011), for example (Huisman 2006):

$$
\text { property }_{t}=\text { property }_{\text {initial }}-R_{\text {property }} \log _{10}(1+t)
$$

in which property $_{t}$ is the value of a particular geotechnical property at time $t$, property initial $_{\text {is }}$ the value of the property initially at time of exposure, i.e. at $t=0, R_{\text {property }}$ is the 'weathering rate' which is property, material, and environment dependent, and $t$ is the time in years (Fig. 13). This relation describes the change in time of a property over the full weathering range from fresh groundmass to residual soil. Huisman (2006) incorporated the $W E$ (weathering) factors of Table 4 in eq. 1, and established the weathering rates $\left(R_{W E}\right)$ for different groundmasses in the Mediterranean climate of Spain (Table 7). Table 7 lists also the dynamic weathering rates and total decrease of property values for various groundmasses after 30 years of exposure in various climates. Table 7 clearly shows the large influence of different climates on the rate of weathering of geotechnical properties and the influence of differences in bedding spacing and presence of soluble materials. 


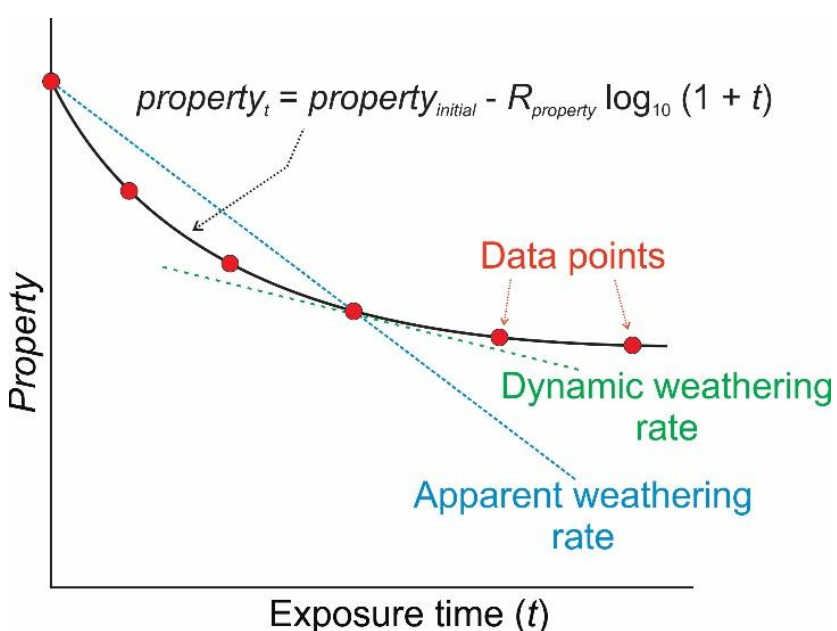

Fig. 13 Property vs exposure time (modified from Huisman 2006)

Table 7 Weathering rate examples

\begin{tabular}{|c|c|c|c|c|c|c|c|c|}
\hline \multirow[t]{2}{*}{ Lithology $^{(1\}}$} & \multirow[t]{2}{*}{ Property ${ }^{(2)}$} & \multirow{2}{*}{$\begin{array}{l}\text { Initial } \\
\text { value }\end{array}$} & \multirow{2}{*}{$\begin{array}{l}R_{w \rightarrow}^{(3)} \\
1 / \log [y r]\end{array}$} & \multirow{2}{*}{$\begin{array}{l}\text { Dynamic } \\
\text { weathering } \\
\text { rate (at } 30 \\
\text { years after } \\
\text { exposure as } \\
\text { percentage } \\
\text { of initial } \\
\text { value) })^{(4)} \\
\% \text { pt./yr } \\
\end{array}$} & \multirow{2}{*}{$\begin{array}{l}\text { Decrease in } \\
30 \text { years after } \\
\text { exposure (as } \\
\text { percentage } \\
\text { from initial } \\
\text { value) }^{(4)} \\
\\
\%\end{array}$} & \multirow{2}{*}{$\begin{array}{l}\text { Indicative } \\
\text { timespan }\end{array}$} & \multicolumn{2}{|c|}{ Climate $^{(5)}$} \\
\hline & & & & & & & \multirow{7}{*}{ Csa } & \multirow{7}{*}{$\begin{array}{l}\text { Mediter- } \\
\text { ranean }\end{array}$} \\
\hline Clay-containing limestone (bedding spacing $<0.1 \mathrm{~m}$ ) ${ }^{(a)}$ & WE & 1 & 0.052 & -0.073 & 7.8 & $40]$ & & \\
\hline Clay-containing limestone (bedding spacing $>0.1 \mathrm{~m}$ ) ${ }^{(a)}$ & WE & 1 & 0.042 & -0.059 & 6.3 & 40 & & \\
\hline Limestone (medium-thick bedded) ${ }^{(a)}$ & WE & 1 & 0.067 & -0.094 & 10 & 40 & & \\
\hline Calcareous shale (clay-/mudstone) ${ }^{(a)}$ & WE & 1 & 0.169 & -0.24 & 25 & 40 & & \\
\hline Gypsum-cemented siltstone ${ }^{(a)}$ & $W E$ & 1 & 0.325 & -0.46 & 48 & 40 & & \\
\hline Gypsum (beds consisting of gypsum) ${ }^{(a)}$ & WE & 1 & 0.133 & -0.19 & 20 & 40 & & \\
\hline Sandstone $^{(0)}$ & IRS & $105 \mathrm{MPa}$ & 34 & -0.45 & 48 & 30 & $\mathrm{Am}$ & \multirow{3}{*}{ Tropical } \\
\hline Gneiss/schist ${ }^{(6)(c)}$ & Index prop ${ }^{17\}}$ & & & -1.15 & 35 & 35 & Aw & \\
\hline Gneiss/schist ${ }^{(6)(\mathrm{c})}$ & Strength ${ }^{(8)}$ & & & -1.14 & 34 & 35 & Aw & \\
\hline Tuffaceous sandstone $e^{(d)}$ & $R_{S}$ & $863 \mathrm{~N} / \mathrm{mm}$ & & -0.34 & 60 & $3,000]$ & \multirow[b]{2}{*}{ Csb } & \multirow{2}{*}{$\begin{array}{l}\text { Tempe- } \\
\text { rate }\end{array}$} \\
\hline Mudstone ${ }^{(d)}$ & $R_{S}$ & $235 \mathrm{~N} / \mathrm{mm}$ & & -0.17 & 21 & 3,000 & & \\
\hline
\end{tabular}

Notes: (1) Data (a-c) from cut slopes, (d) from natural terraces. (2) WE: weathering factor from SSPC (Hack et al. 2003); IRS: Intact Rock Strength, $R_{S O}$ : Penetration strength based on needle penetration hardness. (3) $R_{W E}$ : (Weathering rate) follows eq. 1 . (4) Dynamic weathering rate and total decrease follow logarithmic relation for data from $(a, b)$, linear relation for (c), and exponential relation for (d). (5) Climate according Kottek and Rubel (2017). (6) Completely weathered material and residual soil only. (7) Various index properties of soil, such as Unit Weight, porosity, and saturated conductivity. (8) Various shear and unconfined strength properties. Data: (a) Huisman et al. (2006) (b) Tating et al. (2013) (c) Tran et al. (2019) (d) Hachinohe et al. (2000).

\section{8 'Hard' layers and crusts}

Weathering normally weakens the groundmass, but may also cause forming of various 'hard' layers that are harder and stronger than the surrounding groundmass (Winkler 2014; Bland and Rolls 1998). Examples are 'duricrust', 'hardpan', 'calcrete', 'laterite', and 'caprock' in dredging (Chesworth 2008). In geotechnical work these are often simply identified by 'hard layer', 'cemented horizon' or 'crust'. Hard layer development is mostly due to precipitation of in groundwater-dissolved minerals, such as salts, carbonates, and iron compounds. Chemical reactions between minerals in different groundwater flows, chemical reactions between in groundwaterdissolved minerals and ground materials, and evaporation of water cause precipitation. Solution of minerals due to weathering at another location may be the source of the in groundwater-dissolved minerals, but these may also stem from other sources, such as vegetation or influence of humans, e.g. fertilizer. Hard layer development may be at surface due to, for example, evaporating groundwater, but can also be below surface, or at or below the sea floor. Existence and location of hard layers are often difficult to predict. The processes involved depend on many local and regional variables that may change over short distance both horizontally and vertically leading to often

\footnotetext{
${ }^{1}$ Note that caprock has multiple meanings: a 'caprock' in geomorphology is a mostly stronger layer that is more resistant to weathering and erosion overlying weaker and less resistant layers. 'Caprock' may be used also for impermeable layers overlying a salt body protecting the salt from solution by rain and groundwater, and in the petroleum industry 'caprock' in used for an impermeable layer capping an oil or gas reservoir.
} 
highly irregular hard layers (Khalifa et al. 2009; Vervoort and De Wit 1997). Hard layers may also occur at locations where these would not be formed at present but are a relic from the (geological) past. Hard layers are common in arid and tropical environments but occur also in Mediterranean and temperate climates.

Most common hard layers are the following. A 'duricrust' is a strong and hard layer at or near the surface formed by the accumulation of precipitated minerals by evaporating capillary or seepage water. The thickness is normally a couple of centimeters. A 'hardpan' is similar but may also refer to an impermeable, strong layer in a soil mass just below the surface. The soil particles are bond by silica or iron compounds (iron oxides) with calcium carbonate. Hardpan is used also for hard layers formed due to compaction by heavy traffic or cementation by chemicals originating from polluted groundwater. Hard surfaces for temporary roads in arid climates are made in the same way by compaction of the surface layer with simultaneously spraying with salt water. The water evaporates and the precipitated salt cements the soil particles. The intact rock strength of duricrusts and hardpans ranges from material that is easy to crumble by hand to strong rock. 'Laterites' are usually residual soils in a tropical environment cemented by iron compounds (oxides and hydroxides) (Blight 1989) and the strength may also range from easy to crumble to strong rock (see also section 1.2). In dredging the term 'caprock' is used for stronger cemented layers with intact rock strength values of more than 10 to $20 \mathrm{MPa}$ in a weaker groundmass. Caprocks are generally layers of conglomerate, breccia, or sand cemented by calcareous, siliceous, or ferruginous material, normally between 10 and $50 \mathrm{~cm}$ thick, and may occur as multiple closely spaced layers at or near the sea floor (Verhoef 1997). 'Calcretes' are comparable to caprocks formed with calcareous cement but are formed onshore near surface (Alonso-Zarza and Wright 2010). Calcretes may be meters thick, irregular, laterally extend over hundreds of meters, and be very strong with intact rock strength values exceeding $100 \mathrm{MPa}$.

\section{Tests to establish the state of weathering and susceptibility to weathering}

The state of weathering as is can be estimated in laboratory and in-situ field tests by comparing test values for the weathered ground material or groundmass to the same but unweathered material or mass. This may give an indication how weathering has influenced the material or mass. Susceptibility to weathering can be established to a certain extent in laboratory tests, however, the long timespan in reality has to be simulated within a timespan suitable for laboratory testing. For example, freeze-thaw tests with cycling between freezing and thawing conditions within days to simulate seasons. Chemical and physical processes in the ground such as diffusion, may be accelerated in time by using centrifuges. Sample size is limited and effectively restricted to testing of disturbed intact ground material only. Whether the samples and simulated conditions in laboratory tests are representative for reality is often questionable. There are no tests available for determining the susceptibility to weathering of groundmasses in-situ over periods up to 50 to 100 years. This is obvious considering the necessary dimensions of the volume to be tested and the timespan over which tests have to be executed.

\subsection{Laboratory testing}

Laboratory ultrasonic velocity measurements may give an idea about the state of weathering as is of a piece of intact ground by referencing to the measured ultrasonic velocities in a piece of the same but unweathered ground (Chawre 2018; ASTM D2845-08 2008). Higher velocities indicate less weathering and vice versa. It should be noted that there is no direct relation between the state of weathering and ultrasonic velocity. Also, the ultrasonic velocity does not give information on the susceptibility to weathering.

Climate chambers are used to simulate the influence on ground of a changing environment, for example, day - night temperatures, changing seasons, freezing and thawing, and regular wetting and drying due to rainfall (Barros De Oliveira Frascá and Yamamoto 2006; ASTM D5313/D5313M-12 2013; ASTM D5312/D5312M-12 2013). These may be combined with centrifuges (Tristancho et al. 2012). Humidity cells are used to simulate weathering of solids for among other weathering of and chemical changes in mine waste material (ASTM D574418 2018). The influence of salt, for example, from sea spray, can be tested by regularly spraying samples with water with dissolved salts (ASTM D5240/D5240M-12e1 2013). Crystallization tests determine the resistance of intact ground to crystallization processes of, for example, salt in pores in rock (BS EN 12370:1999 1999).

Slaking tests are often used to indicate the susceptibility to weathering of intact ground material, for example, the slake durability and the Los Angeles abrasion tests; the later mostly used for determining the durability of toughness and abrasion resistance of aggregate for road pavement (Ulusay and Hudson 2007; Dick and Shakoor 1995; Hack 1998; Hack and Huisman 2002; Nicholson 2000; ASTM D4644-16 2016; ASTM C131/C131M-14 
2014; Franklin and Chandra 1972; Nickmann et al. 2006). The tests submerge material in water in a rotating drum and the volume of material that falls apart in a particular timespan is a measure for the durability.

Dropping a block of rock from a certain height to investigate how the intact rock fractures under impact ('Drop Test', CIRIA 2007), and cyclic stressing-destressing tests (Lagasse et al. 2006) may be useful for establishing intact rock integrity. These tests may indicate indirectly the ease with which intact rock fractures due to weathering or how easy incipient discontinuities change into mechanical discontinuities.

\subsection{In-situ testing}

Indirectly an indication on the state of weathering of a groundmass may be derived from seismic wave characteristics such as wave velocity or wave amplitude (Table 3). Measured seismic wave velocities are higher if the wave travels through fresh ground and slower through weathered masses, partially because the measured waves may have travelled around weathered parts of the mass and thus have a longer ray path. The wave amplitude is a function of among others, the absorption of energy in the ground which is higher in weathered than fresh unweathered ground. The wave velocity and amplitude should be correlated to states of weathering established on borehole cores. Seismic waves do not directly give information on the susceptibility to weathering but may give depth of weathering and the thickness of weathered layers. The depth of weathering may in turn give an idea on the rate of weathering as larger depth of weathering in the subsurface often also implies a higher rate.

Other geophysical methods that indirectly give an idea about the state of and susceptibility to weathering are resistivity and electro-magnetic measurements as these react to the presence of clay that in many grounds will be more present in weathered than unweathered parts of the ground.

\section{Conclusion}

Weathering is a process that governs many engineering applications on and in the Earth. It often transforms originally sound ground into soft ground. Quantities of weathered material do not need to be large as small volumes of ground weathered in a brief time span drastically can change geotechnical properties. Weathering is the reason for many constructions and other engineering applications in which ground is used, to become a disaster. Tests to determine the susceptibility to weathering representative for realistic volumes of groundmass do not exist and published data on time-weathering-degradation relations for groundmasses are few. Therefore, forecasting the influence of weathering on geotechnical properties has to be done by the design engineer based on experience and a-priori knowledge without much or no hard data at all. Many engineers do not realize the importance of weathering or are hesitant in taking decisions based on own expertise and a-priori knowledge alone. They may assess the state of weathering as is, may mention the existence of future or susceptibility to weathering in general terms in the reporting, but do nothing to implement the consequences in design and construction. Fortunately, the safety factor used in civil engineering instigates excess in design to accommodate for uncertainties in the construction. One of these is ground and future behavior of ground, and therefore not all constructions fail even if susceptibility to weathering is not but should have been taken into account.

\section{References}

Ahnert F (1994) Equilibrium, scale and inheritance in geomorphology. Geomorphology 11 (2):125-140. doi:10.1016/0169555X(94)90077-9

Allison RJ, Bristow GE (1999) The effects of fire on rock weathering: some further considerations of laboratory experimental simulation. Earth Surf Proc Land 24 (8):707-713. doi:10.1002/(SICI)1096-9837(199908)24:8<707::AIDESP993>3.0.CO;2-Z

Alonso-Zarza AM, Wright VP (2010) Calcretes. In: Alonso-Zarza AM, Tanner LH (eds) Carbonates in Continental Settings; Facies, Environments, and Processes, vol 61. 1 edn. Elsevier, Amsterdam, pp 225-267

Anderson RS, Anderson SP (2010) Geomorphology: The Mechanics and Chemistry of Landscapes. Cambridge University Press,

Anon. (1995) The description and classificatioin of weathered rocks for engineering purposes. Q J Eng Geol Hydroge 28 (3):207-242. doi:10.1144/gsl.qjegh.1995.028.p3.02

ASTM C131/C131M-14 (2014) Standard Test Method for Resistance to Degradation of Small-Size Coarse Aggregate by Abrasion and Impact in the Los Angeles Machine. ASTM International, West Conshohocken, PA, USA. doi:10.1520/C0131_C0131M-14

ASTM D2845-08 (2008) Standard Test Method for Laboratory Determination of Pulse Velocities and Ultrasonic Elastic Constants of Rock (Withdrawn 2017). ASTM International, West Conshohocken, PA, USA. doi:10.1520/D2845-08

ASTM D4644-16 (2016) Standard Test Method for Slake Durability of Shales and Other Similar Weak Rocks. ASTM International, West Conshohocken, PA, USA. doi:10.1520/D4644-16 
ASTM D5240/D5240M-12e1 (2013) Standard Test Method for Evaluation of Durability of Rock for Erosion Control Using Sodium Sulfate or Magnesium Sulfate. ASTM International, West Conshohocken, PA, USA. doi:10.1520/D5240_D5240M-12R13E01

ASTM D5312/D5312M-12 (2013) Standard Test Method for Evaluation of Durability of Rock for Erosion Control Under Freezing and Thawing Conditions. ASTM International, West Conshohocken, PA, USA. doi:10.1520/D5312_D5312M-12R13

ASTM D5313/D5313M-12 (2013) Standard Test Method for Evaluation of Durability of Rock for Erosion Control Under Wetting and Drying Conditions. ASTM International, West Conshohocken, PA, USA. doi:10.1520/D5313_D5313M$12 \mathrm{R} 13$

ASTM D5744-18 (2018) Standard Test Method for Laboratory Weathering of Solid Materials Using a Humidity Cell. ASTM International, West Conshohocken, PA, USA. doi:10.1520/D5744-18

Barros De Oliveira Frascá MH, Yamamoto JK Ageing tests for dimension stone - experimental studies of granitic rocks from Brazil; paper no. 224. In: Culshaw MG, Reeves HJ, Jefferson I, Spink TW (eds) 10th International Congress of the International Association for Engineering Geology and the Environment IAEG; Engineering geology for tomorrow's cities, Nottingham, UK, 6-10 September 2006 2006. Geological Society of London, p 9

Begonha A, Sequeira Braga MA (2002) Weathering of the Oporto granite: geotechnical and physical properties. Catena 49 (12):57-76. doi:10.1016/S0341-8162(02)00016-4

BGS Arsenic (2001) Arsenic contamination of groundwater in Bangladesh; Vol2: Final report (BGS Technical Report WC/00/19, Volume 2). vol 2. British Geological Survey (BGS); Department for International Development (DFID); Government of the People's Republic of Bangladesh, Keyworth, UK

Bieniawski ZT (1989) Engineering rock mass classifications : a complete manual for engineers and geologists in mining, civil, and petroleum engineering. Wiley, New York

Bland W, Rolls D (1998) Weathering: An Introduction to the Scientific Principles. Arnold Publishers, London

Blight GE Design assessment of saprolites and laterites; Invited lecture; General report/Discussion session 6. In: Publications Committee of the XII ICSMFE (ed) 12th International Conference on Soil Mechanics and Foundation Engineering, Rio de Janiero, 13-18 August 1989 1989. Balkema, Rotterdam, pp 2477-2484

Bracke G, Salah S, Gauthier-Lafaye F (2001) Weathering process at the natural fission reactor of Bangombé. Environ Geol 40 (4):403-408. doi:10.1007/s002540000189

Brattli B, Broch E (1995) Stability problems in water tunnels caused by expandable minerals. Swelling pressure measurements and mineralogical analysis. Eng Geol 39 (3-4):151-169. doi:10.1016/0013-7952(95)00009-5

BS 5930:1999 (1999) Code of practice for site investigations. British Standards Institution, London

BS EN 12370:1999 (1999) Natural stone test methods - Determination of resistance to salt crystallisation. British Standards Institution, London

Cabria XA (2015) Effects of weathering in the rock and rock mass properties and the influence of salts in the coastal roadcuts in Saint Vincent and Dominica. University of Twente, Enschede, Netherlands

Caves Han-sur-Lesse (2018) Caves of Han-sur-Lesse. http://www.grotte-de-han.be/en/the-cave-of-han. Accessed 24 March 2018

Chawre B (2018) Correlations between ultrasonic pulse wave velocities and rock properties of quartz-mica schist. Journal of Rock Mechanics and Geotechnical Engineering 10 (3):594-602. doi:10.1016/j.jrmge.2018.01.006

Chesworth WE (2008) Encyclopedia of Soil Science. Encyclopedia of Earth Sciences Series, 2 edn. Springer, Dordrecht, The Netherlands

CIRIA (2007) The Rock Manual. The use of rock in hydraulic engineering. 2 edn. CIRIA; CUR; CETMEF, C683, London

Colman SM (1981) Rock-weathering rates as functions of time. Quaternary Res 15 (3):250-264. doi:10.1016/00335894(81)90029-6

Cummings RA, Kendorski FS, Bieniawski ZT (1984) Caving Rock Mass Classification and Support Estimation. Engineers International Inc., Chicago.

Da Conceição FT, Dos Santos CM, De Souza Sardinha D, Navarro GRB, Godoy LH (2015) Chemical weathering rate, denudation rate, and atmospheric and soil CO2 consumption of Paraná flood basalts in São Paulo State, Brazil. Geomorphology 233:41-51. doi:10.1016/j.geomorph.2014.10.040

Dearman WR (1995) Description and classification of weathered rocks for engineering purposes: the background to the BS5930:1981 proposals. Q J Eng Geol Hydroge 28 (3):267-276. doi:10.1144/gsl.Qjegh.1995.028.P3.05

Dethier DP, Lazarus ED (2006) Geomorphic inferences from regolith thickness, chemical denudation and CRN erosion rates near the glacial limit, Boulder Creek catchment and vicinity, Colorado. Geomorphology 75 (3):384-399. doi:10.1016/j.geomorph.2005.07.029

Dick JC, Shakoor A (1995) Characterizing durability of mudrocks for slope stability purposes. In: Haneberg WC, Anderson SA (eds) Clay and Shale Slope Instability; Reviews in Engineering Geology, vol 10. The Geological Society of America, Boulder, CO, USA, pp 121-130. doi:10.1130/REG10-p121

Didier C, Van der Merwe N, Betournay M, Mainz M, Kotyrba A, Aydan Ö, Josien J-P, Song W-K (2008) Mine closure and post-mining management; International state-of-the-art. International Commission on Mine Closure; International Society for Rock Mechanics (ISRM),

Doehne E, Price CA (2010) Stone Conservation: An Overview of Current Research. 2 edn. Getty Conservation Institute, Los Angeles, CA, USA

Dosseto A, Buss HL, Suresh PO (2012) Rapid regolith formation over volcanic bedrock and implications for landscape evolution. Earth and Planetary Science Letters 337-338:47-55. doi:10.1016/j.epsl.2012.05.008

Ehlen J (1999) Fracture characteristics in weathered granites. Geomorphology 31 (1-4):29-45. doi:10.1016/S0169$555 X(99) 00071-9$ 
Ehlen J (2002) Some effects of weathering on joints in granitic rocks. CATENA 49 (1-2):91-109. doi:10.1016/S03418162(02)00019-X

Feddema JJ, Meierding TC (1987) Marble weathering and air pollution in Philadelphia. Atmospheric Environment (1967) 21 (1):143-157. doi:10.1016/0004-6981(87)90279-4

Fookes PG (1997) Tropical Residual Soils; A Geological Society Engineering Group Working Party revised report. Professional handbooks. The Geological Society, London

Fookes PG, Gourley CS, Ohikere C (1988) Rock weathering in engineering time. Q J Eng Geol Hydroge 21:33-57

Franklin JA, Chandra R (1972) The slake-durability test. Int J Rock Mech Min 9 (3):325-328. doi:10.1016/01489062(72)90001-0

Gambolati G, Putti M, Teatini P, Camporese M, Ferraris S, Stori GG, Nicoletti V, Silvestri S, Rizzetto F, Tosi L (2005) Peat land oxidation enhances subsidence in the Venice watershed. Eos, Transactions American Geophysical Union 86 (23):217-220. doi:doi:10.1029/2005EO230001

GCO (1990) Foundation Properties of Marble and Other Rocks in the Yuen Long-Tuen Mun Area. vol 2/90. Geotechnical Control Office, Civil Engineering Services Department, Hong Kong

Ghosh NC, Singh RD Groundwater arsenic contamination in India: vulnerability and scope for remedy. In: 5th Asian Regional Conference of INCID, Special Session on Groundwater, New Delhi, India, 9-11 December 2009 2009. Indian National Committee on Irrigation and Drainage (INCID); International Commission on Irrigation and Drainage (ICID), New Delhi, p 24

Hachinohe S, Hiraki N, Suzuki T (2000) Rates of weathering and temporal changes in strength of bedrock of marine terraces in Boso Peninsula, Japan. Eng Geol 55 (1-2):29-43. doi:10.1016/s0013-7952(99)00104-0

Hack HRGK (1996) Slope stability probability classification SSPC. ITC/Technical University, Delft

Hack HRGK (1998) Slope stability probability classification; SSPC; 2nd version. University of Technology Delft; International Institute for Aerospace Survey and Earth Sciences; ITC, Delft, Enschede, Netherlands

Hack HRGK, Huisman M Estimating the intact rock strength of a rock mass by simple means. In: Van Rooy JL, Jermy CA (eds) 9th congress of the International Association for Engineering Geology and the Environment (IAEG); Engineering geology for developing countries, Durban, South Africa, 16-20 September 2002 2002. IAEG \& South African Institute for Engineering and Environmental Geologists (SAIEG), Houghton, South Africa, pp 1971-1977

Hack HRGK, Price DG Quantification of weathering. In: Marinos PG, Koukis GC, Tsiambaos GC, Stournaras GC (eds) Engineering Geology and the Environment, Athens, 23-27 June 1997 1997. Balkema, Taylor \& Francis Group, Rotterdam, pp 145-150

Hack HRGK, Price DG, Rengers N (2003) A new approach to rock slope stability - A probability classification (SSPC). B Eng Geol Environ 62 (2):167-184. doi:https://doi.org/10.1007/s10064-002-0155-4

Harris CS, Hart MB, Varley PM, Warren CD (1996) Engineering Geology of the Channel Tunnel. Thomas Telford, London

Hencher SR (2015) Practical Rock Mechanics. 1 edn. CRC, Taylor \& Francis Group, Boca Raton, FL, USA, Boca Raton, FL, USA

Hoek E, Brown ET (2018) The Hoek-Brown failure criterion and GSI - 2018 edition. Journal of Rock Mechanics and Geotechnical Engineering:online. doi:10.1016/j.jrmge.2018.08.001

Hughes M, Bonapace P, Rigbey S, Charalambu H An innovative approach to tunneling in the swelling Queenston Formation of Southern Ontario. In: Traylor MT, Townsend JW (eds) Rapid excavation and tunneling conference; RETC 2007, Toronto, Canada, 10-13 June 2007 2007. Society of Mining, Metallurgy and Exploration (SME), Littleton, Co, USA, pp 901-912

Huisman M (2006) Assessment of rock mass decay in artificial slopes. University Delft/ITC, Delft/Enschede

Huisman M, Hack HRGK, Nieuwenhuis JD (2006) Predicting Rock Mass Decay in Engineering Lifetimes: The Influence of Slope Aspect and Climate. Environ Eng Geosci 12 (1):39-51. doi:10.2113/12.1.39

Huisman M, Nieuwenhuis JD, Hack HRGK (2011) Numerical modelling of combined erosion and weathering of slopes in weak rock. Earth Surf Proc Land 36 (13):1705-1714. doi:10.1002/esp.2179

ISO 14689-1:2017 (2017) Geotechnical investigation and testing; Identification, description and classification of rock. International Organization for Standardization, Geneva, Switzerland

James P, Chester D, Duncan A (2000) Volcanic soils: their nature and significance for archaeology. In: McGuire WJ, Griffiths DR, Hancock PL, Stewart IS (eds) The Archaeology of Geological Catastrophes, vol 171. vol 1. Geological Society of London, Special Publications, London, pp 317-338. doi:10.1144/gsl.sp.2000.171.01.23

Katongo C Ground conditions and support systems at 1 shaft, Konkola mine, Chililabombwe, Zambia. In: The Third Southern African Conference on Base Metals : 'Southern Africa's response to changing global base metals market dynamics', Kitwe, Zambia, 26-29 June 2005 2005. The South African Institute of Mining and Metallurgy, Johannesburg, pp 253-280

Khalifa MA, Kumon F, Yoshida K (2009) Calcareous duricrust, Al Qasim Province, Saudi Arabia: Occurrence and origin. Quaternary International 209 (1-2):163-174. doi:10.1016/j.quaint.2009.02.014

Knight J, Grab SW (2014) Lightning as a geomorphic agent on mountain summits: Evidence from southern Africa. Geomorphology 204:61-70. doi:10.1016/j.geomorph.2013.07.029

Kottek M, Rubel F (2017) World maps of Köppen-Geiger climate classification; version March 2017. Veterinärmedizinische Universität Wien; Climate Change \& Infectious Diseases. http://koeppen-geiger.vu-wien.ac.at/present.htm. Accessed 10 January 2019

Krajick K (2005) Fire in the Hole; Raging in mines from Pennsylvania to China, coal fires threaten towns, poison air and water, and add to global warming. Smithsonian Magazine May (25 April 2019)

Krank KD (1980) The effects of weathering on the engineering properties of Sierra Nevada granodiorites. University of Nevada, Reeno 
Kuenzer C, Stracher GB (2012) Geomorphology of coal seam fires. Geomorphology 138 (1):209-222. doi:https://doi.org/10.1016/j.geomorph.2011.09.004

Lagasse PF, Clopper PE, Zevenbergen LW, Ruff JF (2006) Riprap Design Criteria, Recommended Specifications, and Quality Control; NCHRP; Report 568. Transportation Research Board (TBR), Washington, D.C.

Lainé M, Balan E, Allard T, Paineau E, Jeunesse P, Mostafavi M, Robert JL, Le Caër S (2017) Reaction mechanisms in swelling clays under ionizing radiation: influence of the water amount and of the nature of the clay mineral. RSC Advances 7 (1):526-534. doi:10.1039/C6RA24861F

Lamp JL, Marchant DR, Mackay SL, Head JW (2017) Thermal stress weathering and the spalling of Antarctic rocks. Journal of Geophysical Research: Earth Surface 122 (1):3-24. doi:10.1002/2016jf003992

Laubscher DH, Jakubec J (2001) The MRMR rock mass classification for jointed rock masses. In: Hustrulid WA, Bullock RL (eds) Underground Mining Methods: Engineering Fundamentals and International Case Studies. Society for Mining, Metallurgy \& Exploration, Inc. (SME), Littleton, CO, USA, pp 475-481

Lebedeva MI, Fletcher RC, Brantley SL (2010) A mathematical model for steady-state regolith production at constant erosion rate. Earth Surf Proc Land 35 (5):508-524. doi:10.1002/esp.1954

Lim SS, Martin CD (2010) Core disking and its relationship with stress magnitude for Lac du Bonnet granite. Int J Rock Mech Min 47 (2):254-264. doi:https://doi.org/10.1016/j.ijrmms.2009.11.007

Lumb P (1983) Engineering properties of fresh and decomposed igneous rocks from Hong Kong. Eng Geol 19 (2):81-94. doi:10.1016/0013-7952(83)90027-3

Lumpkin GR, Gao Y, Gieré R, Williams CT, Mariano AN, Geisler T (2014) The role of Th-U minerals in assessing the performance of nuclear waste forms. Mineralogical Magazine 78 (5):1071-1095. doi:10.1180/minmag.2014.078.5.01

Machado SL, Vilar OM, Carvalho MF (2008) Constitutive model for long term municipal solid waste mechanical behavior. Computers and Geotechnics 35 (5):775-790. doi:10.1016/j.compgeo.2007.11.008

Marques EAG, Barroso EV, Menezes Filho AP, Vargas Jr EdA (2010) Weathering zones on metamorphic rocks from Rio de Janeiro-Physical, mineralogical and geomechanical characterization. Eng Geol 111 (1-4):1-18. doi:10.1016/j.enggeo.2009.11.001

Massey JB, Irfan TY, Cipullo A The characterization of granitic saprolitic soils. In: Publications Committee of the XII ICSMFE (ed) Proceedings of the 12th International Conference on Soil Mechanics and Foundation Engineering (ICSMFE), Rio de Janeiro, 13-18 August 1989 1989. A.A. Balkema, Rotterdam, pp 533-542

Matsukura Y, Hirose T (2000) Five year measurements of rock tablet weathering on a forested hillslope in a humid temperate region. Eng Geol 55 (1):69-76. doi:10.1016/S0013-7952(99)00107-6

Meierding TC (1993) Marble tombstone weathering and air pollution in North America. Annals of the Association of American Geographers 83 (4):568-588. doi:10.1111/j.1467-8306.1993.tb01954.x

Meshik AP (2009) The Workings of an Ancient Nuclear Reactor. Scientific American January (19 April 2019)

Miščević P, Vlastelica G (2014) Impact of weathering on slope stability in soft rock mass. Journal of Rock Mechanics and Geotechnical Engineering 6 (3):240-250. doi:https://doi.org/10.1016/j.jrmge.2014.03.006

Morgan N (2016) Gravestone geology. Geology Today 32 (4):154-159. doi:10.1111/gto.12146

Mottershead DN (1989) Rates and patterns of bedrock denudation by coastal salt spray weathering: A seven-year record. Earth Surf Proc Land 14 (5):383-398. doi:10.1002/esp.3290140504

Nicholson DT (2000) Deterioration of Excavated Rockslopes: Mechanisms, Morphology and Assessment. University of Leeds, Leeds, UK

Nickmann M, Spaun G, Thuro K Engineering geological classification of weak rocks; paper no. 492. In: Culshaw MG, Reeves HJ, Jefferson I, Spink TW (eds) 10th International Congress of the International Association for Engineering Geology and the Environment IAEG; Engineering geology for tomorrow's cities, Nottingham, UK, 6-10 September 2006 2006. Geological Society of London, p 9

Nóbile JC, Martini MA, Dávila FM (2017) Cosmogenic 10Be denudation rates and geomorphometric analysis in the Ambato range $\left(28^{\circ}-29^{\circ} \mathrm{S}\right)$, Sierras Pampeanas, Argentina. Quaternary International 438:80-91. doi:10.1016/j.quaint.2016.01.009

Ohta T (2001) Core Disking and "Rockburst" in Soft Tuffaceous Rock Masses at Iwate Tunnel. Quarterly Report of RTRI 42 (3): 130-135. doi:10.2219/rtriqr.42.130

Olesen O, Dehls JF, Ebbing J, Henriksen H, Kihle O, Lundin E (2007) Aeromagnetic mapping of deep-weathered fracture zones in the Oslo Region - a new tool for improved planning of tunnels. Norwegian Journal of Geology 87 (1/2):253267

Oyama T, Chigira M (2000) Weathering rate of mudstone and tuff on old unlined tunnel walls. Eng Geol 55 (1-2):15-27. doi:10.1016/S0013-7952(99)00103-9

Pesendorfer M, Loew S (2004) Hydrogeologic. Exploration. during. Excavation. of. the. Lötschberg. Base. Tunnel. (AlpTransit. Switzerland). In: Hack HRGK, Azzam R, Charlier R (eds) Engineering geology for infrastructure planning in Europe; A European perspective, vol 104. Lecture notes in earth sciences. Springer, Berlin, Heidelberg, pp 347-358

Pickles A Rock mass classification for pile foundations. In: The Characterization of Rock Masses for Engineering Purposes, City University, Hong Kong, 25 June 2005 2005. The Geological Society, Hong Kong Regional Group, Hong Kong, p 36 slides

Pieters CM, Noble SK (2016) Space weathering on airless bodies. Journal of Geophysical Research: Planets 121 (10):18651884. doi:10.1002/2016JE005128

Price DG (1995) A suggested method for the classification of rock mass weathering by a ratings system. Q J Eng Geol Hydroge $26(1): 69-76$ 
Price DG (2000) Dolerite once exposed at Stirling Castle, Scotland (personal communication). Delft

Price DG, De Freitas MH, Hack HRGK, Higginbottom IE, Knill JL, Maurenbrecher M (2009) Engineering geology; principles and practice. Springer-Verlag, Berlin, Heidelberg. doi:10.1007/978-3-540-68626-2

Qi S, Yue ZQ, Wu F, Chang Z (2009) Deep weathering of a group of thick argillaceous limestone rocks near Three Gorges Reservoir, Central China. Int J Rock Mech Min 46 (5):929-939. doi:10.1016/j.ijrmms.2009.03.006

Rahaman W, Wittmann H, von Blanckenburg F (2017) Denudation rates and the degree of chemical weathering in the Ganga River basin from ratios of meteoric cosmogenic 10Be to stable 9Be. Earth and Planetary Science Letters 469:156169. doi:10.1016/j.eps1.2017.04.001

Rainey TP, Rosenbaum MS (1989) The adverse influence of geology and groundwater on the behaviour of London Underground railway tunnels near Old Street Station. Proceedings of the Geologists' Association 100 (1):123-134. doi:10.1016/S0016-7878(89)80071-9

Reißmüller M (1997) Rottachtales zwischen Bodenschneid, Stolzenbert und Siebligrat sowie Geotechnische Eigenschaften verwitterter Kössener Mergel. Technical University of Munich, Munich, Germany

Rocscience (2011) Disturbance factor; Rock Mass Strength Analysis using the Generalized Hoek-Brown failure criterion. Rocscience Inc. http://www.rocscience.com. Accessed 14 October 2013

Rodriguez-Navarro C, Doehne E, Sebastian E (1999) Origins of honeycomb weathering: The role of salts and wind. GSA Bulletin 111 (8):1250-1255. doi:10.1130/0016-7606(1999)111<1250:OOHWTR >2.3.CO;2

Ruiz-Agudo E, Putnis CV, Rodríguez-Navarro YC Role of chemical weathering in salt decay of ornamental stone. In: Proc. MACLA 7, XXVII Reunión De La Sociedad Española De Mineralogía, Jaén, Spain, 11-14 September 20072007. pp 29-29

Ruxton BP (1968) Measures of the Degree of Chemical Weathering of Rocks. J Geol 76 (5):518-527

Schmitz R, Schroeder C Urban site investigation in the Belgian karst belt; paper 801. In: Culshaw MG, Reeves HJ, Jefferson I, Spink TW (eds) 10th International congress International Association of Engineering Geology and The Environment (IAEG2006); Engineering geology for tomorrow's cities, Nottingham, UK, 6-10 September 20062009. Geological Society of London, London, p 10

Schoonejans J, Vanacker V, Opfergelt S, Ameijeiras-Mariño Y, Christl M (2016) Kinetically limited weathering at low denudation rates in semiarid climatic conditions. Journal of Geophysical Research: Earth Surface 121 (2):336-350. doi:10.1002/2015JF003626

Selby MJ (1980) A rock mass strength classification for geomorphic purposes: with tests from Antarctica and New Zealand. Zeitschrift für Geomorphologie 24 (1):31-51

Selby MJ (1993) Hillslope Materials and Processes; 2nd edition. Oxford University Press, Oxford, UK

Shao Y, Raupach MR, Findlater PA (1993) Effect of saltation bombardment on the entrainment of dust by wind. Journal of Geophysical Research: Atmospheres 98 (D7):12719-12726. doi:10.1029/93JD00396

Sim CK, Kim SS, Lucey PG, Garrick-Bethell I, Choi Y-J (2017) Asymmetric Space Weathering on Lunar Crater Walls. Geophysical Research Letters 44 (22):11,273-211,281. doi:10.1002/2017gl075338

Singh A (2004) FRHI-a system to evaluate and mitigate rock fall hazard in stable rock excavations. Journal of The Institution of Engineers (India); Civil Engineering Division 85:62-75

Singh H, Huat BBK (2004) Origin, formation and occurrence of tropical residual soils. In: Huat BBK, Gue SS, Ali FH (eds) Tropical Residual Soils Engineering. 1 edn. CRC Press, London, pp 1-34

Singh VP, Singh P, Haritashya UK, (eds) (2011) Encyclopedia of Snow, Ice and Glaciers. Springer Netherlands, Dordrecht, The Netherlands

Snee C Engineering Geology and cavern design for New York City. In: Roach MF, Kritzer MR, Ofiara D, Townsend BF (eds) 9th North American Tunnelling. NAT 2008, San Francisco, 8-11 June 2008 2008. Society for Mining, Metallurgy \& Exploration, Littleton, CO, USA, pp 364-372

Soppe WJ, Prij J (1994) Radiation Damage in a Rock Salt Nuclear Waste Repository. Nuclear Technology 107 (3):243-253. doi:10.13182/NT94-A35005

Stacey TR (1982) Contribution to the mechanism of core discing. Journal of the South African Institute of Mining and Metallurgy 82 (9):269-274

Tating FF, Hack HRGK, Jetten VG (2013) Engineering aspects and time effects of rapid deterioration of sandstone in the tropical environment of Sabah, Malaysia. Eng Geol 159 (0):20-30. doi:10.1016/j.enggeo.2013.03.009

Tating FF, Hack HRGK, Jetten VG (2015) Weathering effects on discontinuity properties in sandstone in a tropical environment: case study at Kota Kinabalu, Sabah Malaysia. B Eng Geol Environ 74 (2):427-441. doi:https://doi.org/10.1007/s10064-014-0625-5

Tating FF, Hack HRGK, Jetten VG (2019) Influence of weathering-induced iron precipitation on properties of sandstone in a tropical environment. Q J Eng Geol Hydroge 52 (1):46-60. doi:https://doi.org/10.1144/qjegh2017-143

Taylor HW (1980) A geomechanics classification applied to mining problems in the Shabanie and King Chrysotile asbestos mines, Rhodesia. M.P., University of Rhodesia, Harare, Zimbabwe

Tran TV, Alkema D, Hack HRGK (2019) Weathering and deterioration of geotechnical properties in time of groundmasses in a tropical climate. Eng Geol 260:105221. doi:https://doi.org/10.1016/j.enggeo.2019.105221

Tristancho J, Caicedo B, Thorel L, Obregón N (2012) Climatic Chamber With Centrifuge to Simulate Different Weather Conditions. Geotechnical Testing Journal 35 (1):159-171. doi:https://doi.org/10.1520/GTJ103620

Trudgill ST, Viles HA, Inkpen R, Moses C, Gosling W, Yates T, Collier P, Smith DI, Cooke RU (2001) Twenty-year weathering remeasurements at St Paul's Cathedral, London. Earth Surf Proc Land 26 (10):1129-1142. doi:10.1002/esp.260

Tuğrul A (2004) The effect of weathering on pore geometry and compressive strength of selected rock types from Turkey. Eng Geol 75 (3-4):215-227. doi:10.1016/j.enggeo.2004.05.008 
Ulusay R, Hudson JA (eds) (2007) The Blue Book; The Complete ISRM Suggested Methods for Rock Characterization, Testing and Monitoring: 1974-2006. Commission on Testing Methods ISRM. International Society for Rock Mechanics (ISRM), Turkish National Group, Ankara, Turkey

Utili S, Crosta GB (2011) Modeling the evolution of natural cliffs subject to weathering: 1. Limit analysis approach. Journal of Geophysical Research: Earth Surface 116 (F1). doi:10.1029/2009JF001557

Vanacker V, Bellin N, Molina A, Kubik PW (2014) Erosion regulation as a function of human disturbances to vegetation cover: a conceptual model. Landscape Ecology 29 (2):293-309. doi:10.1007/s10980-013-9956-Z

VanDerwerker T, Zhang L, Ling E, Benham B, Schreiber M (2018) Evaluating Geologic Sources of Arsenic in Well Water in Virginia (USA). International Journal of Environmental Research and Public Health 15 (4):787

Vázquez M, Ramírez S, Morata D, Reich M, Braun J-J, Carretier S (2016) Regolith production and chemical weathering of granitic rocks in central Chile. Chemical Geology 446:87-98. doi:10.1016/j.chemgeo.2016.09.023

Verhoef PNW (1997) Implications for the Site Investigation of Rock Dredging Projects. Taylor \& Francis, Rotterdam

Vervoort A, De Wit K (1997) Correlation between dredgeability and mechanical properties of rock. Eng Geol 47 (3):259-267. doi:10.1016/S0013-7952(97)00023-9

Welch AH, Westjohn DB, Helsel DR, Wanty RB (2000) Arsenic in Ground Water of the United States: Occurrence and Geochemistry. Groundwater 38 (4):589-604. doi:j.1745-6584.2000.tb00251.x

Wellman HW, Wilson AT (1965) Salt Weathering, a Neglected Geological Erosive Agent in Coastal and Arid Environments. Nature 205:1097. doi:10.1038/2051097a0

Wenner D, Wannenmacher H Alborz Service Tunnel in Iran: TBM tunnelling in difficult ground conditions and its solutions. In: Proceedings of the1st Regional and 8th Iranian Tunneling Conference, Tehran, Iran, 18-20 May 20092009. Iranian Tunnelling Association (IRTA) \& Tarbiat Modares University,Tehran, Iran, Tehran, Iran, pp 342-353

Wilson MJ (2004) Weathering of the primary rock-forming minerals: processes, products and rates. Clay Minerals 39 (3):233266. doi:https://doi.org/10.1180/0009855043930133

Winkler E (2014) Stone in Architecture; Properties, Durability. Berlin, Heidelberg, Springer-Verlag

Winkler EM (1986) The Measurement of Weathering Rates of Stone Structures: A Geologist's View. APT Bulletin 18 (4):6570. doi: $10.2307 / 1494233$

Wu C, Xia C, Li Z Safety Assessment System for Evaluating Spontaneous Combustion of Sulfide Ores in Mining Stope. In: Huang P, Wang Y, Li S, Zheng C, Mao Z (eds) Progress in Safety Science and Technology, Proceedings International Symposium on Safety Science and Technology (2006 ISSST), Changsha, China, 24-27 October 2006 2006. China Occupational Safety and Health Association, Beijing Institute of Technology, Science Press, Beijing, China, pp 15991603

Yokota S, Iwamatsu A (2000) Weathering distribution in a steep slope of soft pyroclastic rocks as an indicator of slope instability. Eng Geol 55 (1-2):57-68. doi:10.1016/S0013-7952(99)00106-4 